This is an Open Access version of the published article: Zenebe A, Vanmaercke M, Poesen J, Verstraeten G, Haregeweyn N, Haile M, Amare K, Deckers J, Nyssen J (2013) Spatial and temporal variability of river flows in the degraded semi-arid tropical mountains of northern Ethiopia.

Zeitschrift für Geomorphologie 57: 143-169.

\title{
Spatial and temporal variability of river flows in the degraded semi-arid tropical mountains of northern Ethiopia
}

Amanuel Zenebe ${ }^{\mathrm{a}}$, Matthias Vanmaercke ${ }^{\mathrm{b}, \mathrm{c}}$, Jean Poesen ${ }^{\mathrm{b}}$, Gert Verstraeten $^{\mathrm{b}}$, Nigussie Haregeweyn ${ }^{\mathrm{a}}$, Mitiku Haile $^{\mathrm{a}}$, Kassa Amare ${ }^{\mathrm{d}}$, Jozef Deckers ${ }^{\mathrm{b}}$, Jan Nyssen ${ }^{\mathrm{e}, *}$

${ }^{a}$ Department of Land Resources Management and Environmental Protection, Mekelle University, POBox 231, Mekelle, Ethiopia

${ }^{b}$ Department of Earth and Environmental Sciences, K.U.Leuven, Celestijnenlaan 200E, B-3001 Heverlee, Belgium

${ }^{c}$ Fund for Scientific Research-Flanders, Belgium

${ }^{d}$ Department of Applied Geology, Mekelle University, POBox 231, Mekelle, Ethiopia

${ }^{e}$ Department of Geography, Ghent University, Krijgslaan 281(S8), B-9000 Gent, Belgium

"Corresponding author: jan.nyssen@ugent.be, tel.: + 3292644623

\section{Summary}

Water availability has for long been a critical issue in many developing countries. Despite its enormous potential of water resources, Ethiopia is suffering from a lack of water availability and threatened by the consequences of climate change. Well considered planning to develop these resources is crucial. However, very few observational runoff data exist for this type of environments. Especially runoff data for catchments at the intermediate scale $\left(100-10,000 \mathrm{~km}^{2}\right)$ are lacking. This study assesses the runoff from 10 mediumsized catchments in the Geba river basin, a subcatchment of the Nile in the semi-arid degraded northern Ethiopian highlands. Flow depth records were automatically obtained every 10 minutes during the rainy seasons (July - September) of 2004-2007 and converted to continuous runoff discharge records.

Cumulative annual runoff depths (46-395 mm) are mainly correlated with rainfall depth. Estimated runoff coefficients $(9-47 \%)$ and are negatively correlated with the areal fraction of limestone outcrops in the catchments, indicating runoff transmission losses.

Throughout the rainy season, increases in runoff depth and runoff coefficient were observed, which is partly attributed to an increase in baseflow throughout the season. The majority of the runoff occurs during flash floods, i.e. relatively short runoff events with often very high peak discharges. Characteristics of these floods 
are discussed with some examples, including an exceptionally large flood. Taking into account the difficult conditions for river discharge measurements in a country like Ethiopia, this study provides one of the most comprehensive analyses so far of the magnitude and dynamics of river discharges in Ethiopia.

Key words: river discharge, runoff coefficients, flash flood, Geba, Nile, soil and water conservation

\section{Introduction}

The Ethiopian highlands are a fragile environment, suffering from severe land degradation, which is largely induced by extreme poverty, stagnating technology and high population and livestock densities (Nyssen et al., 2004). Although rainfall in the driest regions of northern Ethiopian Highlands is highly erratic and mainly concentrated in a two- or three-months rainy season (Nyssen et al., 2005), agriculture is mainly rainfed. Ethiopia's population is rapidly growing at a rate of $2.6 \%$ per annum (CSA, 2008), leading to an increased demand for food, water and energy. This has led to a large pressure on the water resources in Ethiopia (WOUBE 1999), resulting in insufficient agricultural production and unreliable hydropower production. Whereas the country is well endowed with potential water resources, which are estimated to be around 110 billion $\mathrm{m}^{3} \mathrm{a}^{-1}$, these are unequally distributed over the country (WOUBE 1999, KEBEDE et al. 2006). Very little of the enormous water resource has been developed for agriculture, irrigation, hydropower generation, and industrial purposes. As a result, the country lacks access to clean water and has one of the lowest levels of electrical consumption per capita in the world, exploiting only 1-3\% of the estimated 30,000 MW hydropower potential (SOLOMON 1998). Furthermore, perturbations in the global water cycle, expected to accompany climate warming (ALLEN \& INGRAM 2002), will further affect water availability for many regions (DE WIT \& STANKIEWICZ 2006). This is particularly true for semi-arid regions such as northern Ethiopia, where river discharges are often highly variable within and between years (e.g. KEBEDE et al. 2006).

Various surface water harvesting structures have been built or planned to increase the reliability and availability of water by storing runoff in reservoirs. However, many of these structures in Ethiopia experience difficulties because of a lack of reliable hydrological data during the design stage. This lack of data has been reported for both small (e.g. HAREGEWEYN et al. 2006) and large catchments (e.g. NYSSEN et al. 2004, HUMPREYs et al. 1997). In many instances, dams and reservoirs in Ethiopia have been overdimensioned because runoff coefficient (RC) estimates using standard practices developed in temperate regions are too high (Pers. Comm. of Michael TSEHAYE, Head Bureau of Water Resources, Mines and Energy, Tigray, Ethiopia, 2009).

To allow a better exploitation of the country's water resources, it is important to understand the magnitude, spatial variability and temporal dynamics of runoff discharges at the catchment scale and to develop river discharge assessment methodologies for this region. However, runoff and river discharge studies are generally limited to larger river systems (i.e. $>1000 \mathrm{~km}^{2}$ ) and some small catchments (i.e. $<10 \mathrm{~km}^{2}$ ) 
(NYSSEN et al. 2004, DESCHEEMAEKER et al. 2006a, GIRMAY et al. 2009, NYSSEN et al. 2010). No studies exist for the intermediate catchment scale $\left(100-10,000 \mathrm{~km}^{2}\right)$ in the northern Ethiopian highlands.

A better understanding of the magnitude, dynamics and controls of river discharges in the northern Ethiopian highlands is not only of practical but also of scientific importance. In general, little is known about runoff in semi-arid tropical catchments of Africa due to the limited data availability (WALLING 1999). Worldwide, networks of river gauging stations are phasing out and it is claimed that governments are less capable to monitor water supplies and forecast floods than they were in the 1960s or 1970s (STOKSTAD 1999). High magnitude flood events from seasonal floods in African rivers are causing serious damage (WALLING 1999). Also in Ethiopia, the occurrence of floods is problematic (WOUBE 1999). During the main rainy season, the major rivers of Ethiopia carry high runoff discharges, sometimes in the form of flash floods, resulting in considerable losses of human life and properties (WOUBE 1999, EEWS 2007). Such floods have also a significant geomorphic impact (WALLING 1999, VANMAERCKE et al. 2010). Furthermore, large efforts have been made to mitigate the ongoing land degradation and to conserve soil and water in the northern Ethiopian highlands (DESCHEEMAEKER et al. 2006b, MUNRO et al. 2008). Although these measures have a significant effect at the plot and small catchment scale (e.g. HAREGEWEYN et al. 2005, NYSSEN et al. 2010), their effect at the intermediate catchment scale is less clear. A recent study by VANMAERCKE et al. (2010) indicated that the amount of sediment exported at the catchment scale is strongly controlled by the occurrence and magnitude of flash floods. The effectiveness of soil and water conservation at the catchment scale is therefore closely linked with their ability to reduce the magnitude of these floods. Nevertheless, only very few detailed studies of the characteristics and controls of flash floods exist (BAKER et al. 2004). This is especially the case for the African continent. Practical problems related to logistics, the difficulties to predict the occurrence of a flood and the destruction of measuring equipment by large events often hamper the collection of detailed and reliable data (Baker et al., 2004).

Therefore, the objective of this study was to improve our understanding of runoff dynamics in medium-sized catchments in semi-arid tropical environments. For 10 medium-sized catchments in the Geba river basin in northern Ethiopia, cumulative runoff, i.e. the baseflow and the direct (surface) runoff, was measured during a four-year period. Both the spatial and temporal variability in runoff and their controlling factors was analyzed, which allowed obtaining a comprehensive view on runoff response in the northern Ethiopian Highlands.

\section{Study area}

This study was conducted in the catchment of Geba River, a subcatchment of Tekeze (Atbara) and Nile River (Fig. 1), draining an area (A) of $5133 \mathrm{~km}^{2}$ in the highlands of Tigray, northern Ethiopia. Ten nested subcatchments of the Geba were selected and monitored in this study: Suluh (SU), Genfel (GE), Agula (AG), Ilala (IL), Upper Geba (UG), May Gabat (MY), Endaselassie (EN), Middle Geba (MG), Upper Tankwa (UT) and Lower Tankwa (LT). SU, GE, AG and IL are subcatchments of UG. UG, MY and EN are subcatchments of MG. Furthermore, UT is a subcatchment of LT, which flows in to Geba a few hundred meters downstream 
of the Middle Geba flow gauge (Fig. 1). The river network consists exclusively of single-thread channels, with narrow $(50-150 \mathrm{~m})$ alluvial plains. The catchment has a tropical mountain climate with an extended dry period of nine to ten months and an effective rainy season of 50 to 60 days in July - September (VIRGO \& MUNRO 1978, NYSSEN et al. 2004). Annual rainfall in the Geba catchment varies around $600 \mathrm{~mm}$, but is characterized by large spatial and temporal variations. During the rainy season, convective clouds generally develop at the end of the morning, leading to mostly local rain showers in the afternoon (NYSSEN et al. 2005). Topographical aspects, flow paths of air masses between mountain ranges and local effects such as transversal mountain ridges control the spatial distribution of rainfall more than altitude (NYSSEN et al. 2005).

The Geba catchment is situated at an altitude ranging between 936 and $3314 \mathrm{~m}$ a.s.l. Topography can be described as mountainous with plateaus that are deeply incised by river gorges. Fig. 2 displays the Tankwa river and illustrates the physical environment of this study area. The geology of the Geba catchment consists of a basement complex plateau (metamorphic rocks) having an upper sedimentary rock layer (sandstone, shale, limestone, and limestone-marl) with some doleritic intrusions and capped by basalt trap series. Given the subhorizontal structural relief and the absence of large karst systems (KIBREWOSSEN et al. 2011), no significant inter-basin water transfers are known or expected. The dominant soils in the Geba catchment are (lithic) Leptosols, mainly situated in the mountainous parts of the catchment. On more level lands, Cambisols, often with vertic properties, and Luvisols commonly occur. Fluvisols are found in some parts of the catchment, i.e., where alluvium is present along the narrow incised river valleys (VAN DE WAUW et al. 2008, VIRGO \& MUNRO 1978).

The Geba catchment is extensively cultivated. Agriculture even occurs on many of the steep and stony valley sides. The remnants of the original highland forests are mostly overgrazed and deforested (MUNRO et al. 2008). Effective soil and water conservation structures (such as stone bunds) were constructed throughout the catchment since since 1970s, leading at many places to an improvement of the vegetation cover and reversing the ongoing land degradation (e.g. MUNRO et al. 2008). Based on data compiled from the Bureau of Agriculture and Natural Resources of Tigray (TBoANRD, 2008), estimations of the stone bunds densities per subcatchment were made. As these estimations are only based on the available information on stone bunds, they may underestimate the total number of soil and water conservation structures in the studied catchments. Detailed information on the topography, lithology, land use and stone bund densities per studied subcatchment is given in Table 1 .

\section{Materials and Methods}

\subsection{Hydrometric stations and flow depth data collection}

River gauging stations were established at the outlet of the ten nested subcatchments of the Geba (Table 1). River discharge was measured at these ten flow gauges during the rainy seasons of 2004-2007. Since some gauges were installed after 2004 or were damaged by flash floods, not all stations produced data during these four years (Table 1). 
To allow comparison between catchments and years, each measurement campaign was organized in the same period (12 July to 10 September). In the dry season, the flow gauges were not monitored as the runoff discharges during this period are generally very low. An analyses of available rainfall data indicated that the measuring period accounts on average for $63 \%$ of the annual rainfall.

Each gauging station was equipped with a staff gauge and an automatic pressure transducer (TD-diver), measuring the total pressure of the water column and the temperature at intervals of 10 minutes (VAN ESSEN INSTRUMENTS 2006). The TD-divers and their containers were frequently cleaned after floods to remove the deposited sediments. Three barometric divers were installed at the IL, MY and LT gauging stations to measure the atmospheric pressure every 30 minutes. Data from the barometric divers were used to correct the air pressure of the TD-divers. For the station where no barometric diver was installed, data of the nearest installed baro diver was used.

Apart from these automatic measurements, the flow depth was measured manually from the staff gauge at least once a day and each time a large change in flow depth was observed, i.e. during floods. A comparison of the obtained flow depths with manually recorded flow depths revealed some important deviations. These deviations are mainly attributed to inaccuracies in manual measurements, since measuring flow depths during flash floods at night was often difficult. However, even when only manual measurements, that were found to be reliable, were considered, a systematic underestimation of $16 \%$ on the automatically recorded flow depths of all stations could still be observed $\left(n=608, R^{2}=0.92\right)$. Therefore, barometrically corrected TD-diver data was also corrected for this bias.

Some problems were encountered during the measurement campaigns. Several divers were washed away by flash floods (mainly during the measuring season of 2006), causing gaps in the continuous TD-diver records (Table 2). Furthermore, since the TD-divers were initially installed near the bank of the river channel, i.e. not at its deepest point, no flow depth could be recorded during periods of very low discharge. In 2007, these problems were largely avoided by installing the TD-divers in rectangular reinforced metal boxes in the deepest part of the river bed.

\subsection{Instantaneous runoff discharge measurements}

Simultaneously with the manual flow depth measurements, the flow velocity was estimated. Since the available resources were limited and measuring flow velocity with a current meter was impossible during flash floods, flow velocity was estimated from surface velocity measurements. Surface flow velocity was determined using plastic floats (bottles partially filled with water and bearing a flashlight at night), thrown from the bank at various flow stages for all gauges. Each float velocity measurement was carried out over a distance of $20 \mathrm{~m}$ (10 m upstream and $10 \mathrm{~m}$ downstream of the cross-section) and repeated 3 to 5 times to reduce random variations. The mean value of these surface velocity measurements was converted to the average stream velocity using Prony's equation (GRAF 1998):

$u=0.8 u_{s}$

where $u=$ average velocity $\left(\mathrm{m} \mathrm{s}^{-1}\right)$ and $u_{s}=$ surface velocity $\left(\mathrm{m} \mathrm{s}^{-1}\right)$. 
Channel cross-sectional areas were measured with a total station at the start and end of each measurement campaign and a relation between flow depth $(\mathrm{d}, \mathrm{m})$ and cross-sectional flow area $\left(\mathrm{Af}, \mathrm{m}^{2}\right)$ was established. Instantaneous runoff discharge $\left(\mathrm{Q}, \mathrm{m}^{3} \mathrm{~s}^{-1}\right)$ for all velocity and corresponding flow depth measurements was then calculated as:

$Q=A f \cdot u$

\subsection{Conversion to continuous river discharge series}

Next, instantaneous river discharge measurements, collected over a wide range of flow depths, were used to develop depth-discharge rating curves:

$\mathrm{Q}=\mathrm{a} \mathrm{d}^{\mathrm{b}}$

where $\mathrm{a}$ and $\mathrm{b}$ are fitting parameters.

For the UT flow gauge, two depth-discharge curves were developed since a major flash flood destroyed the original station in 2006 after which it was reinstalled at a location with a different cross-sectional area-depth relation. Details of the calculated rating curves can be found in Table 3. These rating curves were used to convert the automatically recorded continuous flow depth series to river discharge records. The resulting continuous runoff discharge series were integrated on a daily basis, to obtain the daily runoff discharges $\left(\mathrm{Q}_{\mathrm{d}}\right.$, $\mathrm{m}^{3}$ day $\left.^{-1}\right)$.

\subsection{Rainfall data}

Daily rainfall data from 13 manually observed rain gauge stations in the Geba catchment and its surroundings were obtained from the Ethiopian National Meteorological Service Agency (Fig. 1). Similarly to findings of ASFAW (2005) and NYSSEN et al. (2005), no significant relationship was found between mean annual rainfall and altitude for the 13 rainfall stations $\left(R^{2}=0.06, p\right.$-value $\left.=0.4\right)$. Therefore, the point data of the rainfall stations were extrapolated to the catchment level, using the Thiessen polygon method (e.g. RAO et al. 1980).

\subsection{Estimation of missing river discharge data and extrapolation to annual river discharges}

Due to malfunctioning of some TD-divers and because some divers were washed away during flash floods, several stations had no continuous diver records for all measuring campaigns. As a result, the daily river discharge $\left(\mathrm{Q}_{\mathrm{d}}\right)$ could not be determined for some days and stations (Table 2). If this was the case for periods longer than 18 days, no estimation of the total seasonal runoff was made, as the uncertainties were expected to be too large.

If the number of missing days was smaller, the missing $Q_{d}$ values were estimated using regression models (Table 2). For UG and MG, $Q_{d}$ was estimated by making a regression between the observed $Q_{d}$ at these stations and the sum of the observed $\mathrm{Q}_{\mathrm{d}}$ values at the monitored upstream stations. For the stations AG, EN, UT and LT, missing $Q_{d}$ values were predicted with a relationship between the observed $Q_{d}$ values and the daily maximum manually observed flow depth. These models had rather large uncertainties, but performed 
significantly better than models based on daily rainfall or the $\mathrm{Q}_{\mathrm{d}}$ of nearby catchments. Details on the regression models used are given in Table 2.

Furthermore, each measurement campaign was limited to a major part of the summer rainy season (July 12 to September 10). To obtain the river discharge on an annual basis, seasonal river discharges were linearly extrapolated as a function of rainfall, considering the rainfall depth during the measuring campaign and the annual rainfall depth in the catchment.

\subsection{Calculation of runoff coefficients and baseflow estimations}

The total seasonal RC (\%) were calculated by dividing the cumulative seasonal runoff depth by the seasonal rainfall depth per subcatchment for each measurement campaign. Cumulative runoff depth can, however, partly be attributed to baseflow, while the other part consists of direct (surface) runoff. The stream flow hydrographs were therefore separated into baseflow and surface-runoff components using a "smoothed minima technique" similar to that used by Gratiot et al. (2010). For every four days, the lowest recorded runoff discharge from the diver was considered to be a good approximation for the baseflow in these four days, assuming that no runoff event would last more than four days. This period of four days was arbitrarily chosen, based on our field experience. To test the sensitivity of the baseflow estimations for this arbitrarily period, baseflows were also calculated for periods of 2 to 8 days, but yielded generally very similar results with total baseflow estimates varying at most $20 \%$ from the values, based on the four-days-minimum.

\section{Results}

Table 4 provides an overview of the measured seasonal cumulative runoff volumes and depths, the estimated annual cumulative runoff and the estimated seasonal baseflow. The total seasonal runoff depths (TRs) of the monitored subcatchments vary between 34 and $281 \mathrm{~mm}$. The total seasonal runoff coefficients (TRCs) vary between 9 and $46 \%$, with an average of $22.3 \%$. The TRC of each subcatchment and measuring campaign, was used to extrapolate the TRs to cumulative annual runoff depths (TRa), based on the estimated annual rainfall depths. These extrapolations induce additional uncertainty but are the best estimations of the annual runoff that could be made, based on the available data. Nevertheless, measurements were conducted for, on average, $63 \%$ of the annual rainfall depth and the pooled seasonal (2004-2007) rainfall correlated reasonably well with the measured seasonal runoff $\left(\mathrm{R}^{2}=0.44\right.$, Fig. 3$)$. Therefore, the additional induced uncertainty is expected to be acceptable.

On average, an estimated $36 \%$ of the total seasonal runoff is exported as baseflow. However, large differences in the contribution of baseflow exist between the years and stations. A large fraction of the total seasonal runoff is transported during a few large flood events (see section 5.4). Therefore, the occurrence and magnitude of these floods has a large influence on the relative contribution of baseflow.

\section{Discussion}

\subsection{Reliability of the obtained data}


The measured runoff discharges and obtained RCs should be interpreted with caution. As explained in the 'materials and methods' section, various problems occurred during the measuring campaigns. The most important problems were related to the missing diver data and the prediction of Qd-values for days without diver records. However, also the calibrations of the TD-divers and the $\mathrm{d}-\mathrm{Q}$ relationships used induce uncertainties on the estimated runoff discharges. The estimated rainfall depths further add to uncertainties on the estimated RCs. Only data from 13 rain gauges were available to estimate the rainfall in the $4592 \mathrm{~km}^{2}$ catchment (Fig. 1). Due to its convective nature, rainfall in the Ethiopian highlands often occurs very locally (NYSSEN et al. 2005). The average density of one rain gauge per $385 \mathrm{~km}^{2}$ is therefore probably too low to allow accurate estimation of rainfall depths.

Also, the estimated baseflows are subjected to important uncertainties. The separation of hydrographs in baseflow and surface runoff components is a difficult problem, as indicated by various authors (e.g. BRODIE \& HOSTETLER 2005, GRATIOT et al. 2010). The used "smoothed minima technique" assumes that the river discharge returns to the baseflow level at least once during the arbitrarily chosen period (GRATIOT et al. 2010). Estimated contributions of baseflow varied relatively little when this period was varied between 2 and 8 days, i.e. the maximum observed variation in baseflow of was only $20 \%$ of the estimated baseflow for a four day period. For a period of 3-6 days the maximum observed variation was only $12 \%$. However, as rain showers occur almost daily during the rainy season, a new direct runoff event may occur before the baseflow level of the previous runoff event was reached. As this may happen for consecutive days, the minimum measured value during the considered period does not necessarily correspond to the actual baseflow. Another problem, related to the baseflow estimations, is that several TD-divers could not be installed in the deepest point of the river bed. Therefore, actual flow depth was sometimes below the diver level. During these periods, manual gauge readings were made in the deepest point of the cross-section and an average of these manual readings was used to estimate the discharge during periods when the water level did not reach the TD-diver. Although these applied averages have very little effect on the calculated total runoff volumes, they have a significant impact on the estimated baseflow discharges. Estimated contributions of baseflow should therefore be interpreted with caution and only serve as an indication for the importance of baseflow.

\subsection{Spatial variability in runoff}

Despite their uncertainties, the results reveal clear differences in cumulative runoff volume, runoff depths and RCs between the studied subcatchments (Table 4). Evidently, the average discharge for the entire measuring period $\left(\mathrm{Q}_{\mathrm{avg}}, \mathrm{m}^{3} \mathrm{~s}^{-1}\right)$ increases with catchment area $\left(\mathrm{A}, \mathrm{km}^{2}\right)$ :

$\mathrm{Q}_{\text {avg }}=0.0774 \mathrm{~A}^{0.7595}\left(\mathrm{R}^{2}=0.82, \mathrm{n}=10, \mathrm{p}<0.0003\right)$

SYVITSKI \& MILLIMAN (2007) found a very similar relationship between $\mathrm{Q}_{\text {avg }}$ and A, based on a global database of 488 rivers $\left(\mathrm{Q}_{\text {avg }}=0.075 \mathrm{~A}^{0.8}, \mathrm{n}=488, \mathrm{R}^{2}=0.71, \mathrm{p}<0.0001\right)$. The exponent of Eq. 4 is smaller than 1 , indicating that while river discharges increase, area-specific runoff depths $(\mathrm{mm})$ decrease with increasing 
A. This decrease may be attributed to an average decrease in rainfall depth with increasing A given the local character of the erratic rainfall events. Indeed, when the seasonal runoff depths and seasonal rainfall depths of each flow gauge are considered, a statistically significant relationship was found (Fig. 3). Nevertheless, the scatter on this relationship remains very large.

This is also indicated by the large range in estimated total RCs, varying between 9 and $47 \%$ (Table 4). Fig. 4 displays the average total RC of the monitored subcatchments as a function of their catchment area. For comparison, RCs of other rivers in Ethiopia (reported in NYSSEN et al. 2004) have been plotted on this figure as well. Similar to these other rivers, the RCs of Geba's monitored subcatchments tend to decrease with increasing A. However, this relationship is not significant. Other factors therefore need to be taken into consideration.

To identify these factors, Kendall rank correlation coefficients, a non-parametric statistic used to measure the strength of the relationship between two variables (KENDALL 1938), were calculated between the average total runoff coefficient (TRC) of each monitored subcatchment and all catchment characteristics indicated in Table 1 .

A significant negative correlation was found between the average TRCs and the areal fraction of limestone lithology (LST, see Table 1) of each catchment (Fig. 5). (No correlation exists between LST and catchment area or rainfall depth). This negative relationship indicates the importance of runoff transmission losses due to deep infiltration in the limestone formations. This would be in line with previous studies that mention such transmission losses as an explanation for the oberved negative trend between RCs and catchment area in other parts of Ethiopia (BAUDUIN \& DUBREUIL, 1973; NYSSEN et al., 2004).

Further indications of important runoff transmission losses were found when a the daily discharges of the UG catchment are compared with the sum of the daily discharges of its monitored subcatchments (Fig. 6). This was done for the period of 24 July - 10 September 2006, since this was the only period for which daily runoff data for all 5 subcatchments were available. Although UG has a catchment area of $2957 \mathrm{~km}^{2}$ and the sum of its monitored subcatchments only an A of $2735 \mathrm{~km}^{2}$, almost all observed Qd-values at UG are smaller than the sum of the Qd-values of the subcatchments. Only for days with a very high runoff discharge, UG has daily runoff discharges comparable to or larger than the sum of the daily discharges of its subcatchments. For the 49 days of data included in Fig. 6, daily discharge at the UG flow gauge is on average $43 \%$ smaller than the sum of the daily discharges at the monitored subcatchments (49\% when the three days for which the Qd at UG is larger than the sum of the monitored subcatchments are excluded). Runoff transmission losses could be a very plausible explanation for these observed differences, as the Geba flows through a section of limestone and marls for ca. $23 \mathrm{~km}$ between the confluence of SU, GE and AG and the UG flow gauge. This estimated runoff reduction of $43 \%$ would correspond to runoff transmission losses of $1.9 \%$ per kilometer of river length. However, the actual transmission losses are potentially higher since the daily discharges at $\mathrm{UG}$ also include the discharges of an unmonitored catchment $\left(\mathrm{A}=222 \mathrm{~km}^{2}\right)$. Nevertheless, this estimated average transmission loss is in the same order of magnitude as transmission losses in other 
dryland rivers: a compilation of data from various rivers in (semi-)arid areas indicates transmission losses up to $2.5 \%$ per kilometer of river length (ТОOTH 2000).

With the exception of the areal extent of limestone lithology (LST, \%), none of the analysed controlling factors (Table 1) was found to be significantly correlated to the observed seasonal RCs. Although studies in smaller catchments from Tigray have indicated that vegetation cover has a strong positive effect on runoff reduction (e.g. DESCHEEMAEKER et al. 2006a, GIRMAY et al. 2009), no significant correlation between the measured RCs and any variable related to land use was found. Furthermore, NYSSEN et al. (2009) demonstrated for a 200 ha subcatchment of the Geba (May Zegzeg) that the implementation of soil and water conservation measures had a strong reducing effect on the direct runoff. However, no significant relationship was found between the estimated average stone bund density (Table 1) and either the total runoff coefficients or the direct runoff coefficients.

This lack of correlation with vegetation and soil and water conservation measures may be attributed to various factors. Firstly, the spatial data used in the regression analyses is only of limited quality. Because no better land cover map was available, the land use characteristics of Table 1 were derived from a supervised classification of a Landsat image and are therefore susceptible to errors (ZENEBE 2009). Furthermore, the estimated stone bund densities are subjected to uncertainties and probably underestimate the actual density of stone bund and soil and water conservation measures. Secondly, the variation in land cover between the monitored catchments is probably too small to exert a clear impact on the observed RCs. All catchments are dominated by relatively comparable fractions of bare land, crop land and cultivated land, whereas e.g. no catchment is dominated by forest land (Table 1). Similarly, the catchments have relatively little variation in the estimated stone bund densities (i.e. $3.1-5.6 \mathrm{~km} / \mathrm{km}^{2}$ ).

Finally, it can be expected that the observed runoff during the measuring periods not only depends on the estimated rainfall depths and the factors discussed above, but also on the temporal characteristics of the hydrological balance, such as the rainfall intensity, preceding rainfall events and evapotranspiration, particularly in the lowlands. In the section below, the temporal variation in runoff during the measuring campaigns is further explored.

\subsection{Temporal variability in runoff through the rainy season}

During the measuring campaigns, large variations in daily runoff discharges were observed at all flow gauges. As an example, the daily variation of runoff depths and rainfall for the measuring campaign at Ilala 2006 are shown in Fig. 7. A distinction was made between the total runoff depths (i.e. the measured runoff depths), the estimated baseflow depths and the direct runoff depths (i.e. the difference between the total runoff and baseflow depths). The example clearly shows an increase in the daily baseflow depths throughout the rainy season. Although not sufficient observational data are available for other flow gauges and periods due to the inability of the TD-divers to capture all baseflow levels, we could visually observe a similar trend at all stations during the various measuring campaigns. This trend indicates that there is a clear recharge of 
the groundwater table throughout the rainy season, as was also illustrated in a modeling study by ASFAW (2005).

The daily surface runoff (and hence total runoff) depths, generally show relatively good correspondence with the large rainfall events (e.g. Fig 7). However, several smaller rainfall events were recorded by the rain gauges, but could not be detected in the runoff response and vice versa. This is attributed to the local character of many rainstorms. Unfortunately the spatial density of rain gauges was too low to make a more detailed analysis of these differences.

Nevertheless, the available data suggest that for several catchments, the runoff response to rainfall events is generally smaller at the start of the rainy season than towards the end. This is e.g. illustrated for IL in 2006 in Fig. 7. This increase in total runoff response can probably be partly explained by changes in baseflow. However, also the estimated daily surface runoff depths are relatively larger towards the end of the rainy season. This delayed response was observed in the catchments of SU, GE, AG, IL and UG during the measuring campaign 2006, but not for the other catchments. This is illustrated in Fig. 8 (top), where the relative cumulative runoff is shown against the relative cumulative rainfall for all monitored flow gauges in 2006. Also the available data for 2004 and 2005 showed a similar delay in response. However, for 2007, this was much less visible for all stations (Fig. 8, bottom).

The mechanisms, explaining this delayed response are not fully understood. As the rainy season proceeds, a vegetation cover develops. A detailed study for the Agula catchment indicated that mean vegetation cover increases from $26 \%$ at the start of the rainy season to $58 \%$ towards the end of the rainy season (HAGOS 2006). It could be expected that this increase in vegetation cover leads to a reduced runoff response and especially a reduction of the surface runoff discharge. A first explanation for this seemingly contradictory observation might be the earlier mentioned increase in baseflow. Despite the large differences between 2006 and 2007, it can be noted in both years that especially the larger catchments (i.e. MG, UG, SU, GE, AG) have a more delayed response, while smaller catchments (e.g. EN, UT, LT) cluster more around the 1:1-line. This further indicates that the increase in baseflow during the raining season is an important explaining factor for this delayed response in daily runoff.

Another explanation can perhaps be found in the soil properties of the studied catchments. A relatively large fraction of the catchments where this delayed response was observed are covered with soils having vertic properties. These soils have a high infiltration capacity if they are relatively dry (i.e. at the start of the rainy season), but are much less permeable if they become wet (i.e. at the end of the rainy season) (e.g. BAUDUIN \& Dubreuil 1973; Tewodros et al. 2009). Because already a lot of rain fell before the start of the measuring campaign of 2007, this could explain why this delayed response was not observed in 2007, as soils would already be relatively wet before the start of the campaign.

Finally, also the rainfall characteristics can provide a possible explanation for the observed delayed response. As the runoff response of a catchment to a rainfall event can be expected to increase non-linearly with the rainfall depth of an event (this is also true at a seasonal scale, see Fig. 3), we may expect relatively higher RCs for larger rainfall events. In 2006, the most intense rainstorms occured towards the end of the rainy 
season (see e.g. Fig. 6), while in 2007 also some intense rainstorms occured at the start of the rainy season. As a large fraction of the seasonal runoff is transported during a few large flood events, the occurence and magnitude of the largest rainfall events could also help explaining the observed delayed response in some catchments. Unfortunatly, the available rainfall data are insufficiently detailed to analyze this in more detail.

\subsection{Flash floods}

Flash floods occur frequently during the rainy season in the northern Ethiopian highlands. A large fraction of the total seasonal runoff volume is transported during a few large events. This is illustrated in Fig. 9, where for all available flow gauges and measuring campaigns (see Table 1) the cumulative contribution of all recorded 10 minutes-interval runoff discharges to the total measured seasonal runoff discharge is plotted against their observed exceedance frequencies. Although the variation between the different stations and years is large, this graph clearly illustrates the importance of events with a low frequency and a high magnitude: $18-78 \%$ (average 37\%) of the measured runoff was transported by the largest $5 \%$ of all measured discharges. No clear trends could be detected between the different stations or different measuring campaigns. This can be explained by the fact that the magnitude and frequency of large floods varies a lot from year to year and between the studied catchments. However, also the fact that some TD-divers were not installed in the deepest point of the section impedes a clear interepretation of the results: for flow depths below the diver level, an average of the manually measured flow depths was used. This explains also the knickpoints that can be observed in some of the curves of Fig. 9. Nevertheless, this ensemble of measured cumulative distributions clearly illustrates the large temporal variability in instantaneous river discharges of the monitored catchments. On an annual basis, the importance of these high manitude low frequency events becomes even more important as these rivers have a very low (or no) runoff discharge during the dry season. The peak runoff discharges of the observed flash floods are often 50 to 100 times higher than the preceding baseflow discharge. The maximum peak discharges $\left(\mathrm{Qmax}, \mathrm{m}^{3} \mathrm{~s}^{-1}\right)$ recorded during the measuring campaigns are included in Table 4. It should be not noted however, that these values do not correspond with the maximum occuring discharges. At some stations, larger floods occurred but damaged the gauging stations, leading to gaps in the TD-diver records (see Table 2). This is especially the case for MG, where much larger floods are very likely to occur.

Flash floods in the monitored Geba catchments mostly occur during the evening or night as a result of the convective rainshowers that commonly take place in the afternoon (NYSSEN et al. 2005). They are generally characterized by a short rising limb, as flow depths can change from less than 1 meter to 3-8 meters in a very short period. The falling limb of the hydrograph is generally much longer. Typical examples of such floods are given in Fig. 10a for the Agula flow gauge during the measuring campaign of 2007. However, not all floods have this type of hydrographs. The duration of the rising limb varied considerably from less than 10 minutes (i.e. the temporal resolution of the TD-divers) to several hours. Also many events with multiple peaks were observed. An example is shown in Fig. 10b for the Tankwa catchment. In the late afternoon, a double peaked flood was recorded at the Upper Tankwa flow gauge. The flood was also recorded at the 
Lower Tankwa flow gauge about two hours later. Although the hydrographs are similar in shape, peak flow discharges have more than doubled at the Lower Tankwa. Especially the second peak has increased significantly in magnitude. This increase corresponds more or less with the increment in catchment area as the flood travels from the UT to the LT flow gauge (Table 1). Based on the difference in timing of the two peaks at the UT and LT flow gauge, one can estimate that the flood wave of UT arrived approximately two hours later at the LT station. As the distance along the stream between the two flow gauges is $\sim 23 \mathrm{~km}$, the flood wave travelled at a speed of approximatly $12 \mathrm{~km} \mathrm{~h}^{-1}$.

During the night of 26-27 August 2006, a regional thunderstorm caused exceptionally large floods in several of the monitored catchments. Recorded rainfall depths during this event varried from 30 to $40 \mathrm{~mm}$, although actual rainfall depths were probably higher at some places. According to farmers near the Upper Geba flow gauge, a flood of this magnitude was exceptional and did not occur during the preceding decade. However, no historical data exist to confirm this. At many places, including the Agula and Upper Geba catchment, runoff discharge exceeded bankfull discharge and the river inundated the surrounding flood plains. Although the flood destroyed the flow gauges of UG and MG, the TD-diver of UG could be retrieved after the flood. As the measuring scaffold (with the TD-diver in it) fell into the river at a known moment, the measured flow depths after this collapse could be corrected for the diver's new height above the river bed. After the flood, the height of the heighest flood marks were compared with the diver records and showed relatively good agreement. This allowed the reconstruction of the event. Fig. 11 shows the hydrograph of the flood recorded at the UG flow gauge and the SU, GE, AG and IL gauges, located upstream. Unfortunatly the diver of MG was lost and no data is available for this station. Based on these hydrographs, it appears that most of flood originated from the AG catchment, were a maximum discharge $513 \mathrm{~m}^{3} \mathrm{~s}^{-1}$ was recorded. As bankfull discharge was exceeded and the surrounding flood plains were inundated, the actual peak flow discharge could not be determined (see the flat top of the hydrograph in Fig. 11). Also at the UG flow gauge, bankfull discharge was exceeded and discharges above the banklevel could only be estimated. These estimations were made by applying the existing d-Q rating curve. This curve was based only on discharge observation below bankfull discharge. The extrapolation of this curve therefore induces large uncertainties. However, the comparison of the hydrographs of the catchments upstream with the one of UG indicates a relatively good agreemt. If the hydrogaphs of SU, GE, AG and IL are summated, a peak flow discharge of $1020 \mathrm{~m}^{3} \mathrm{~s}^{-1}$ is found. The maximum estimated peak flow discharge at UG is $1740 \mathrm{~m}^{3} \mathrm{~s}^{-1}$. This difference of $720 \mathrm{~m}^{3} \mathrm{~s}^{-1}$ is large, but can at least partly be attributed to the contribution of an unmonitored subcatchment of $222 \mathrm{~km}^{2}$ between AG and the UG flow gauges. Secondly, the hydrograph of AG was 'topped-off' when the water overflew the banks, leading to an underestimation of the peak flow discharge at this station. Thirdly, as the flood wave propagated between the AG and UG gauges, it might have increased in kurtosis, leading to a relatively higher peak discharge compared to the total flood volume. Hence, the error on the estimated peak discharge of UG is most likely less than $720 \mathrm{~m}^{3} \mathrm{~s}^{-1}$. As a majority of the runoff is exported during such large flood events, the calculated total runoff volumes should be interpreted with care. 


\section{Conclusions and scope for further research}

The Ethiopian highlands play a crucial role as a water tower and hence for (future) water availability and storage in eastern Africa. Information on the magnitude, dynamics and the controlling factors of the runoff discharges in these highlands or comparable environments is needed for the further development of available water resources as well as for our understanding of the ongoing geomorphological processes. Since very few data are available, this study aimed at addressing this research need by monitoring ten medium-sized catchments $\left(121-4592 \mathrm{~km}^{2}\right)$ that are representative for the northern Ethiopian highlands during 1 to 4 rainy seasons, to provide the most comprehensive analysis made so far in the degraded semi-arid mountains of northern Ethiopia.

It was found that most of the seasonal runoff discharges occurs during relatively short but intense flash floods with high peak flow discharges. Although uncertainties on the measured runoff data are relatively large, the available data gives a first good indication on the magnitude of these occurring events. Total runoff depths in the rainy season were found to be mainly related to the rainfall depths, while the corresponding RCs (varying between 9 and 47\%) are negatively correlated to the fraction of the catchment with limestone lithologies. This is most likely the result of runoff transmission losses. Measured RCs are generally smaller than estimated values that are often used in dam and reservoir construction schemes and tend to decrease with increasing catchment area. This indicates that several small dams would be more efficient for runoff harvesting purposes than one large reservoir having the same total drainage area.

This pioneering study raised some issues that deserve attention in future research. Firstly, many practical problems were encountered during the measuring campaigns. These were mainly associated with the occurrence of flash floods. Measuring strategies to monitor these very sudden and often very large peak flow events should be further developed. Practical lessons can be learned from this study. Secondly, the observed temporal variability was very high and probably mainly controlled by the occurrence of local thunderstorms. Unfortunately, no detailed spatial rainfall data were available and the interaction between rainfall patterns and the resulting runoff discharges are not yet fully understood. Better spatial (and temporal) rainfall data would probably allow a better understanding of the ongoing dynamics, the shape of the hydrographs and the relative importance of baseflow. Also the potential effect of the many soil and water conservation measures in the catchment could not be identified. It is currently unclear if this is due to the uncertainties on the available data or because these measures have only a limited effect in the studied catchments. The effect of these measures on the reduction of the surface runoff is of great interest, since various studies have indicated that surface runoff is a key factor in the ongoing land degradation processes (e.g. NYSSEN et al. 2010, VANMAERCKE et al. 2010).

\section{Acknowledgements}

This research was funded by the Flemish Inter-University Council (VLIR). Mekelle University is acknowledged for their support. Kim Vanhulle, Annelies Beel, Hailay Hagos, Kedir Mohammed, Isabelle Neyskens, Elke Soumillion, Berhane Berhe, the guards of the monitoring stations and all BSc. students and 
field assistants involved in this research are highly acknowledged for their help with the fieldwork. We would also like to thank the MU-IUC programme and the Land Management Research Group, in particular Gebreyohannes Girmay, Sarah Teweldeberhan, Kassa Teka, Atkilt Girma and Anteneh Getachew for their support. MV received grant-aided support from the Research Foundation - Flanders (FWO), Belgium and at the time of data collection, JN was employed by KULeuven in the framework of the MU-IUC programme.

\section{References}

ALLEN, M.R. \& INGRAM, W.J. (2002): Constraints on future changes in climate and the hydrologic cycle. Nature 419: 224-232. doi:10.1038/nature01092

ASFAW, M.G. (2005): Groundwater recharge and Water Balance assessment in Geba Basin, Tigray, Ethiopia. Unpub. MSc. Thesis, Vrije Universiteit Brussel and K.U. Leuven.

Bauduin, D., Dubreuil, P. (1973). L'inventaire des ressources en eau pour l'aménagement intégré du Bassin du Wabi Shebelle d'Ethiopie. Cahiers ORSTOM, Série Hydrologie 10: 307- 348.

BAKER, V.R., Kochel, R.C. \& PATTON, P.C. (2004): Flood Geomorphology. Willey-Interscience, England, pp. 528.

BRODIE, R.S. \& HOSTETLER, S. (2005): A review of techniques for analysing base-flow from stream hydrographs. Proceedings of the NZHS-IAH-NZSSS 2005 Conference (28 November-2 December 2005 , Auckland, New Zealand), 13 pp. Available online: http://www.connectedwater.gov.au/documents/IAH05_Baseflow.pdf (accessed: Febr. 5, 2011)

CSA (2008): Summary and Statistical Report of the 2007 Population and Housing Census of Ethiopia: Population size by age and sex, Central Statistical Authority (CSA), Addis Ababa.

Descheemaeker, K., Nyssen, J., Poesen, J., Mitiku Haile, Muys, B., Raes, D., Moeyersons, J. \& DECKERS, J. (2006a): Soil and water conservation through forest restoration in exclosures of the Tigray highlands. Journal of the Drylands 1: 118-133.

Descheemaeker, K., Nyssen, J., Rossi, J., Poesen, J., Mitiku Haile, Moeyersons, J. \& Deckers, J. (2006b): Sediment deposition and pedogenesis in exclosures in the Tigray Highlands. Geoderma 132: 291-314. doi:10.1016/j.geoderma.2005.04.027

DE Wit, M. \& Stankiewicz, J. (2006): Changes in Surface Water Supply Across Africa with Predicted Climate Change. Science 311: 1917-1921. doi: 10.1126/science.1119929

EEWS (2007): Alert: Flood Vulnerability and Risk in Ethiopia in 2007, Ethiopian Early Warning System (EEWS) Special Report 02 July, 2007, Addis Ababa. (http://www.ochaeth.org/Reports/downloadable/FloodVulnerabilityandRisks.pdf)

Girmay, G., Singh, B.R., Nyssen, J. \& BorRosen, T.(2009): Runoff and sediment -associated nutrient losses under different land uses in Tigray, Northern Ethiopia. Journal of Hydrology 376: 70-80. doi:10.1016/j.jhydrol.2009.07.066

GRAF, W.H. (1998): Fluvial hydraulics, Flow and Transport Processes in channels of Simple Geometry, Wiley, Chichester, England, 692 pp. 
Gratiot, N., Duvert, C., Collet, L., Vinson, D., NÉmery, J. \& SÁEnZ-Romero, C. (2010): Increase in surface runoff in the central mountains of Mexico: lessons from the past and predictive scenario for the next century. Hydrology and Earth System Sciences 14: 291-300.

HaGos, H. (2006): Temporal Variability of Sediment Discharge in Relation to Rainfall Distribution and Seasonal Land Cover Variability throughout the Rainy Season in Agula Catchment- Tigray, Ethiopia.Unpub. M.Sc. thesis, Department of Land Resources Management and Environmental Protection, Mekelle University.

Haregeweyn, N., Poesen, J., Nyssen, J., Verstraeten, G., De Vente, J., Govers, G., Deckers, J. \& MoEYersons, J. (2005): Specific sediment yield in Tigray-Northern Ethiopia: Assessment and semi-quantitative modelling. Geomorphology 69: 315-331. doi:10.1016/j.geomorph.2005.02.001

Haregeweyn, N., Poesen, J., Nyssen, J., De Wit, J., Mitiku Haile, Govers, G. \& Deckers, J. (2006): Reservoir sedimentation in Tigray (Northern Ethiopia): Characteristics and sediment deposition problems. Land Degradation and Development 17: 211-230. doi: 10.1002/ldr.698

Kebede, S., Travi, Y., Alemayehu., T. \& MARC, V. (2006): Water balance of Lake Tana and its sensitivity to fluctuations in rainfall, Blue Nile basin, Ethiopia. Journal of Hydrology 316: 233-247. doi:10.1016/j.jhydrol.2005.05.011

Kendall, M. (1938): A New Measure of Rank Correlation. Biometrika 30: 81-89.

Kibrewossen Tesfagiorgis, Tesfamichael Gebreyohannes, De SMedt, F., Moeyersons, J., Miruts HAGOS, NYSSEN, J. \& DECKERS, J. (2011): Evaluation of groundwater resources in the Geba basin, Ethiopia. Bulletin of Engineering Geology and the Environment 70: 461-466.

Munro, N.R., Deckers, J., Mitiku Haile, Grove, A.T., PoESEn, J.\& NysSEn, J. (2008): Soil landscapes, land cover change and erosion features of the Central Plateau region of Tigrai, Ethiopia: Photomonitoring with an interval of 30 years. Catena 75: 55-64. doi:10.1016/j.catena.2008.04.009

Nyssen, J., Poesen, J., Moeyersons, J., Deckers, J., Mitiku Haile \& Lang, A. (2004): Human impact on the environment in the Ethiopian and Eritrean highlands - a state of the art. Earth-Science Reviews 64: 273-320. doi:10.1016/S0012-8252(03)00078-3

Nyssen, J., Vandenreyken, H., Poesen, J., Moeyersons, J., Deckers, J., Mitiku Haile, Salles, C. \& Govers, G. (2005): Rainfall erosivity and variability in the Northern Ethiopian Highlands. Journal of Hydrology 311(1-4): 172-187. doi:10.1016/j.jhydrol.2004.12.016

Nyssen, J., Clymans, W., Descheemaeker, K., Poesen, J., Vandecasteele, I., Vanmaercke, M., Mitiku Haile, Nigussie Haregeweyn, Moeyersons, J., Martens, K., Amanuel Zenebe, Van CAmp, M., Tesfamichael Gebreyohannes, Deckers, J. \& WALRAEVEns, K. (2010): Impact of soil and water conservation on catchment hydrological response - a case in northern Ethiopia. Hydrological processes 24: 1880-1895. doi: 10.1002/hyp.7628

RAO, A.R., TAO, P.C. \& RUKVICHAI, C. (1980): Characterization and models of watershed storage. Journal of Hydrology 45: 253-277. 
SOlOMON, S. (1998): Hydropower in Ethiopia: Status, Potential and Prospects, EACE (Ethiopian Association of Civil Engineers), Addis Ababa 1 (1), pp. 1-12.

STOKSTAD, E. (1999): Scarcity of Rain, Stream Gages Threatens Forecasts. Science 285: 1199-1200.

SYVITSKI, J.P.M. \& MiLliman, J.D. (2007): Geology, Geography, and Humans Battle for Dominance over the Delivery of Fluvial Sediment to the Coastal Ocean. The Journal of Geology 15: 1-19.

Tewodros Gebregziabher, Nyssen, J., Govaerts, B., Getnet, F., Behailu, M., Mitiku Haile \& DECKERS, J. (2009): Contour furrows for in situ soil and water conservation, Tigray, Northern Ethiopia. Soil \& Tillage Research 103: 257-264. doi:10.1016/j.still.2008.05.021

TBoANRD (2008): Soil and Water Conservation Report, Tigray Bureau of Agriculture and Natural Resources Development Mekelle, Tigray.

Tоотн, S. (2000): Process, form and change in dryland rivers: a review of recent research. Earth-Science Reviews 51: 67-107. doi:10.1016/S0012-8252(00)00014-3

Van de Wauw, J., Baert, G., Moeyersons, J., Nyssen, J., De Geyndt, K., Nurhussein Taha, Amanuel Zenebe, Poesen, J. \& Deckers, J. (2008): Soil-landscape relationships in the basaltdominated highlands of Tigray, Ethiopia. Catena 75: 117-127. doi:10.1016/j.catena.2008.04.006

VAN ESSEN INSTRUMENTS (2006): Van Essen Instruments Expands Its Range of Diver Data Loggers for Ground Water Monitoring. Ground Water Monitoring \& Remediation 26:193-198

Vanmaercke, M., Amanuel Zenebe, Poesen, J., Nyssen, J., Verstraeten, G. \& Deckers, J. (2010): Sediment dynamics and the role of flash floods in sediment export from medium-sized catchments: a case study from the semi-arid tropical highlands in northern Ethiopia. Journal of Soils and Sediments 10: 611-627. doi: 10.1007/s11368-010-0203-9

VIRGO, K.J. \& MUNRO, R.N. (1978): Soil and erosion features of the central plateau of Tigray, Ethiopia.

Geoderma 20: 131-157. doi:10.1016/0016-7061(78)90040-X

WALLing, D.E. (1996): Hydrology and rivers. In: AdAMs, W.E., Goudie, A.S. \& ORME, A.R. (eds) The physical geography of Africa. Oxford University Press, Oxford, pp 103-121.

WoubE, M. (1999): Flooding and sustainable land-water management in the lower Baro-Akobo river basin, Ethiopia. Applied Geography 19: 235-251. doi:10.1016/S0143-6228(99)00004-1

ZENEBE, A. (2009): Assessment of spatial and temporal variability of river discharge, sediment yield and sediment-fixed nutrient export in Geba River catchment, northern Ethiopia. Dissertation, Katholieke Universiteit, Leuven. 


\section{FIGURES}



Fig. 1: Geba catchment with the location of the river flow gauges and meteorological stations. For abbreviations: see Table 1 . 


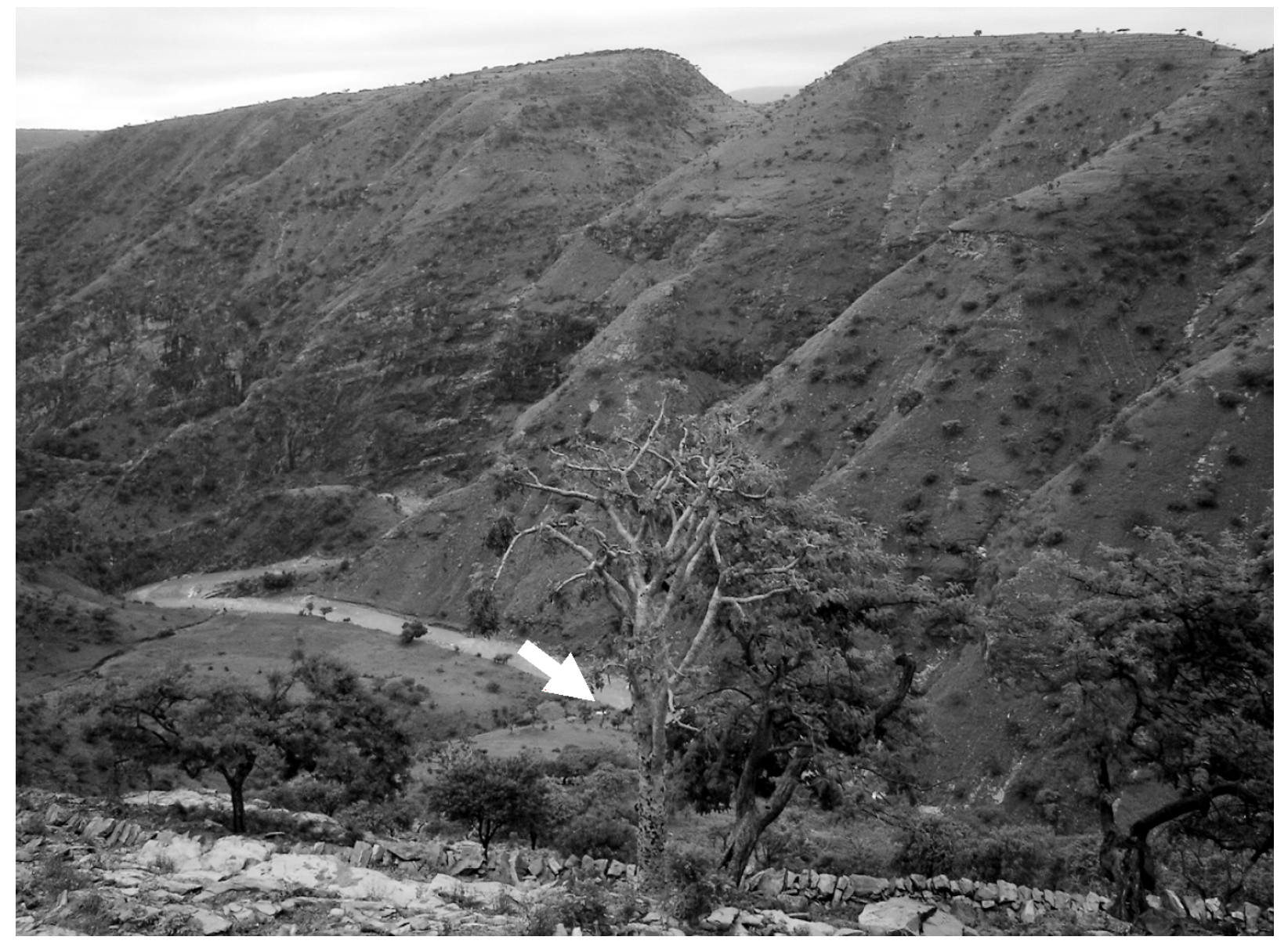

Fig. 2: Tankwa River at the Lower Tankwa (LT) station (September 2006). The white arrow indicates the location of the LT river cross-section. Flow direction from right to left. 


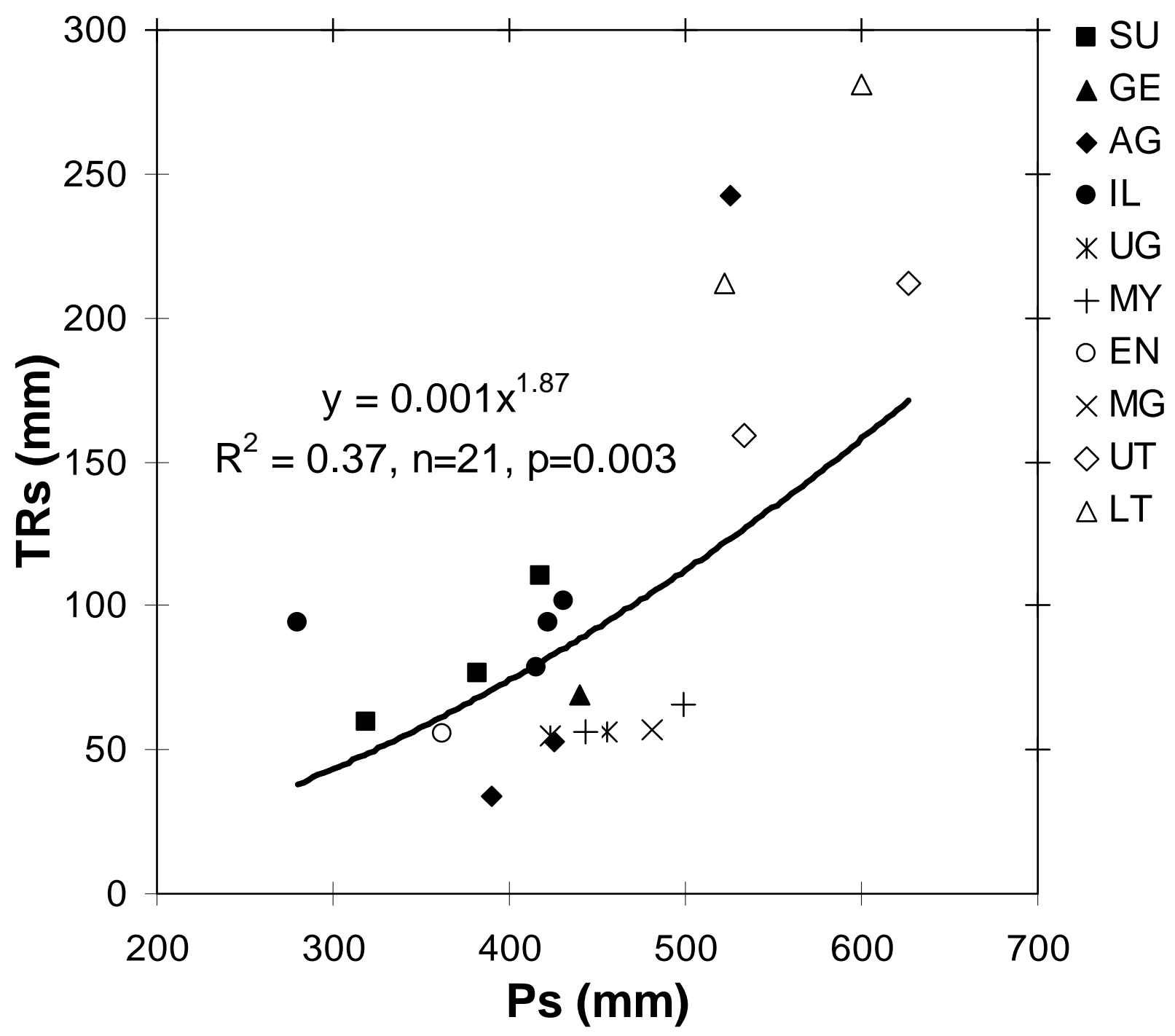

Fig. 3: Cumulative seasonal (12 July - 10 September) rainfall depths (Ps) and corresponding total seasonal runoff depths (TRs) for the studied subcatchments. Values for the individual catchment-years are given in Table 4. Meaning of the abbreviations is given in Table 1. 

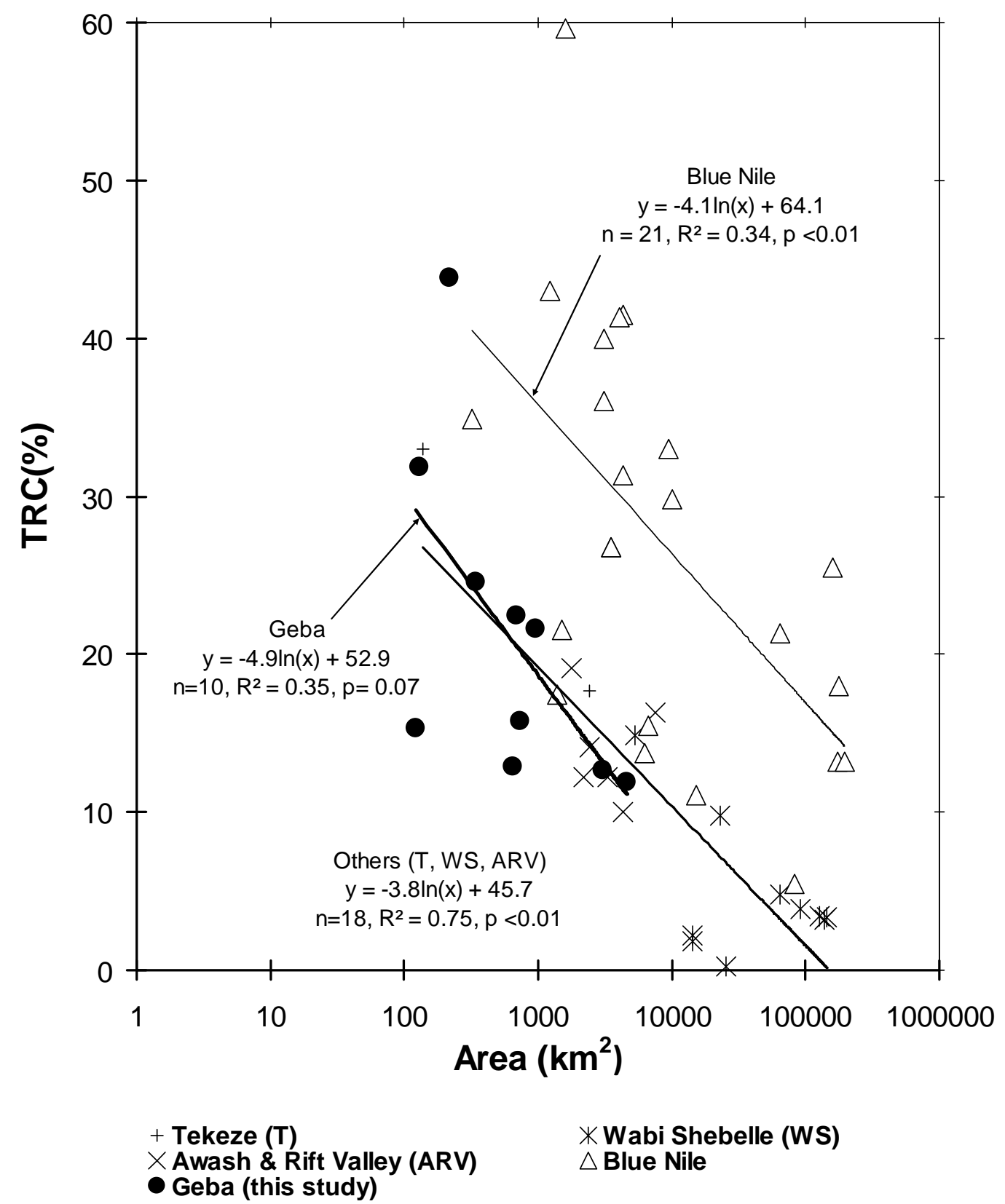

* Wabi Shebelle (WS) $\triangle$ Blue Nile

Fig. 4: Total (seasonal) runoff coefficients (TRC) vs. drainage area of Geba sub-catchments (this study, see Table 4) in comparison with annual RC for other Ethiopian rivers (data from NYSSEN et al. 2004). 


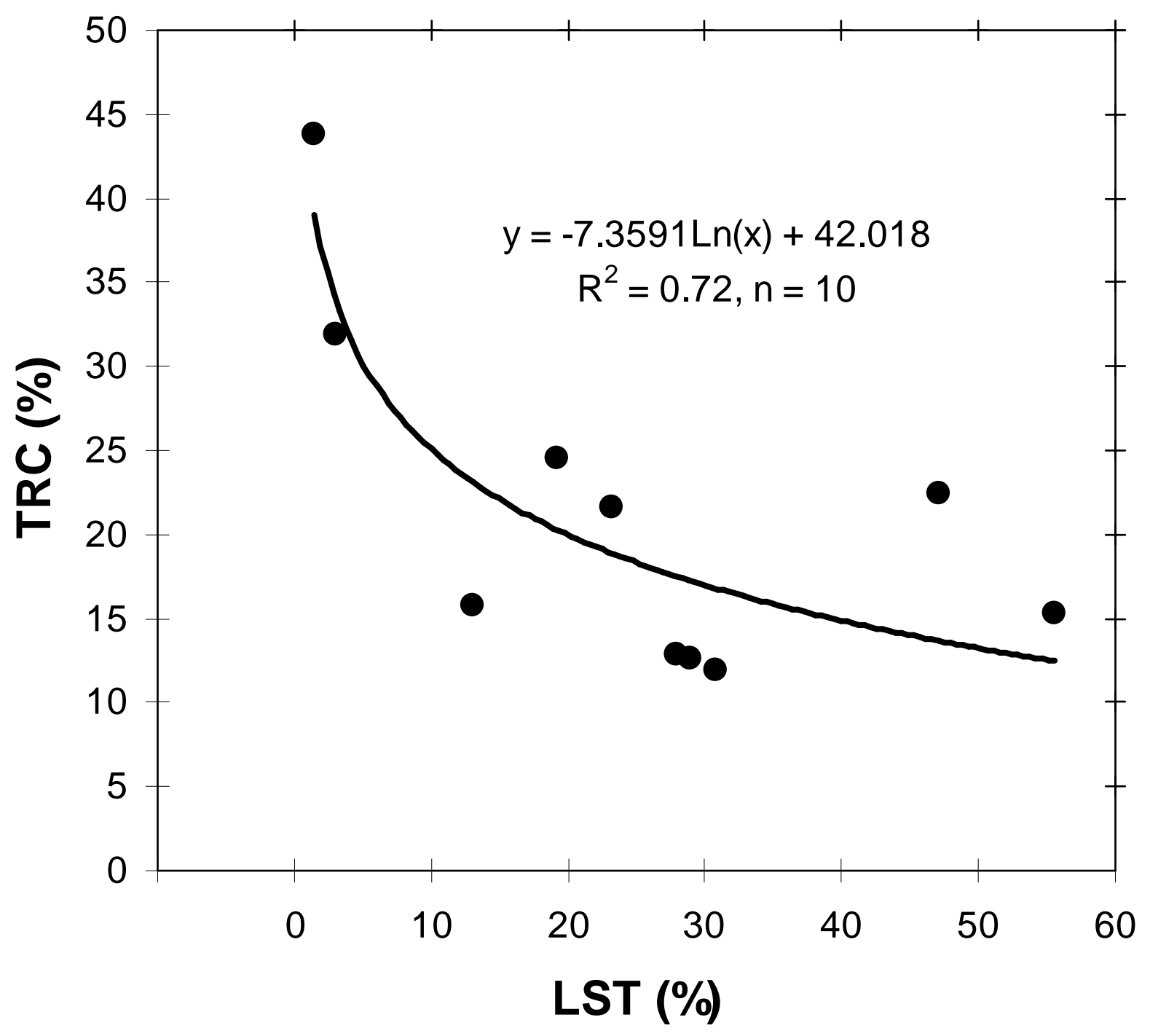

Fig. 5: Relationship between areal fraction of the catchment occupied by limestone lithologies (LST) and the total seasonal runoff coefficient (TRC) of each monitored catchment. 


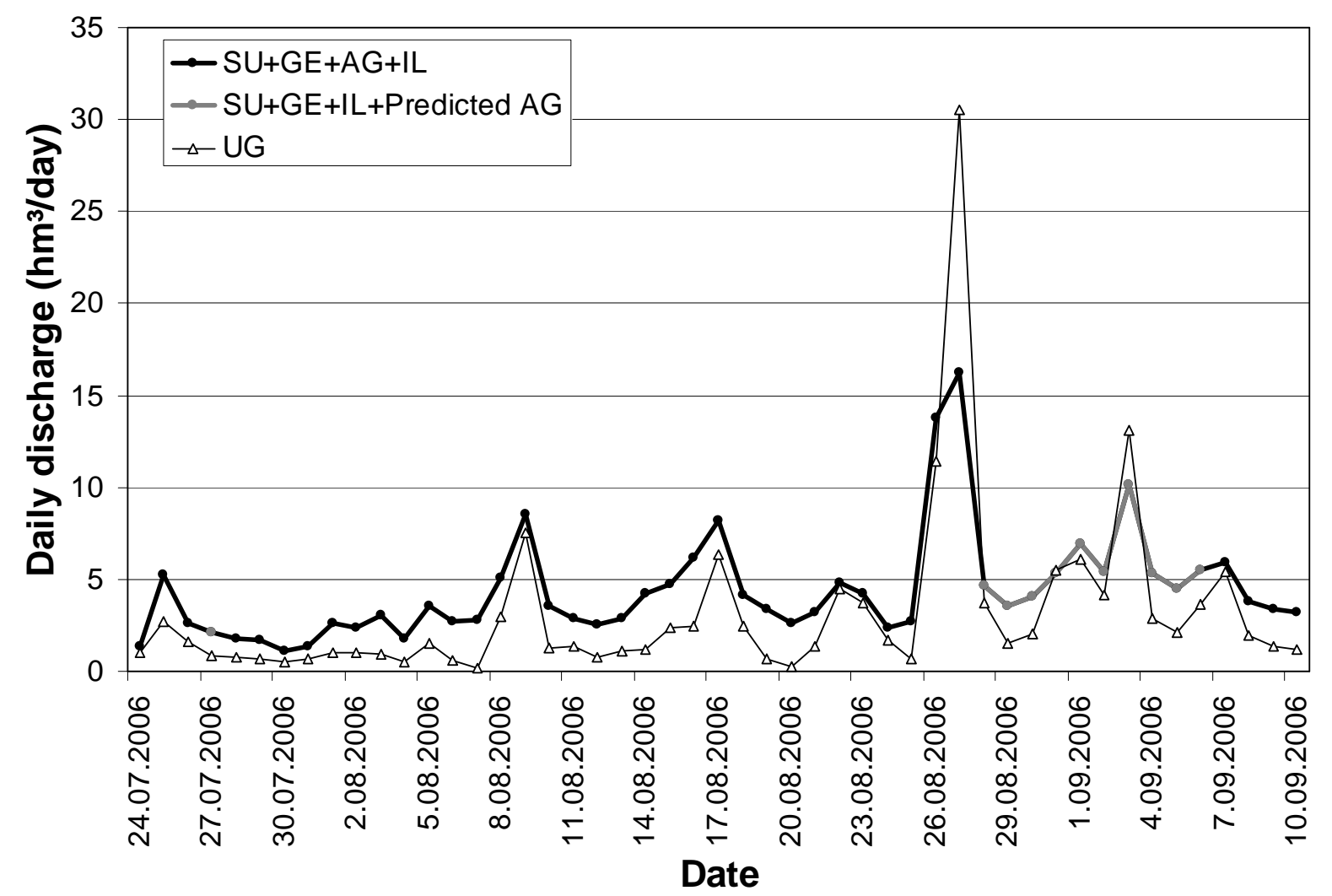

Fig. 6: Measured daily runoff discharges at the UG flow gauge and addition of runoff discharges at the monitored tributaries of UG for the period 24 July - 10 September 2006 (49 days). Due to incomplete diver records, the daily discharge of the AG station in early September was predicted by a regression model (see Table 2) 


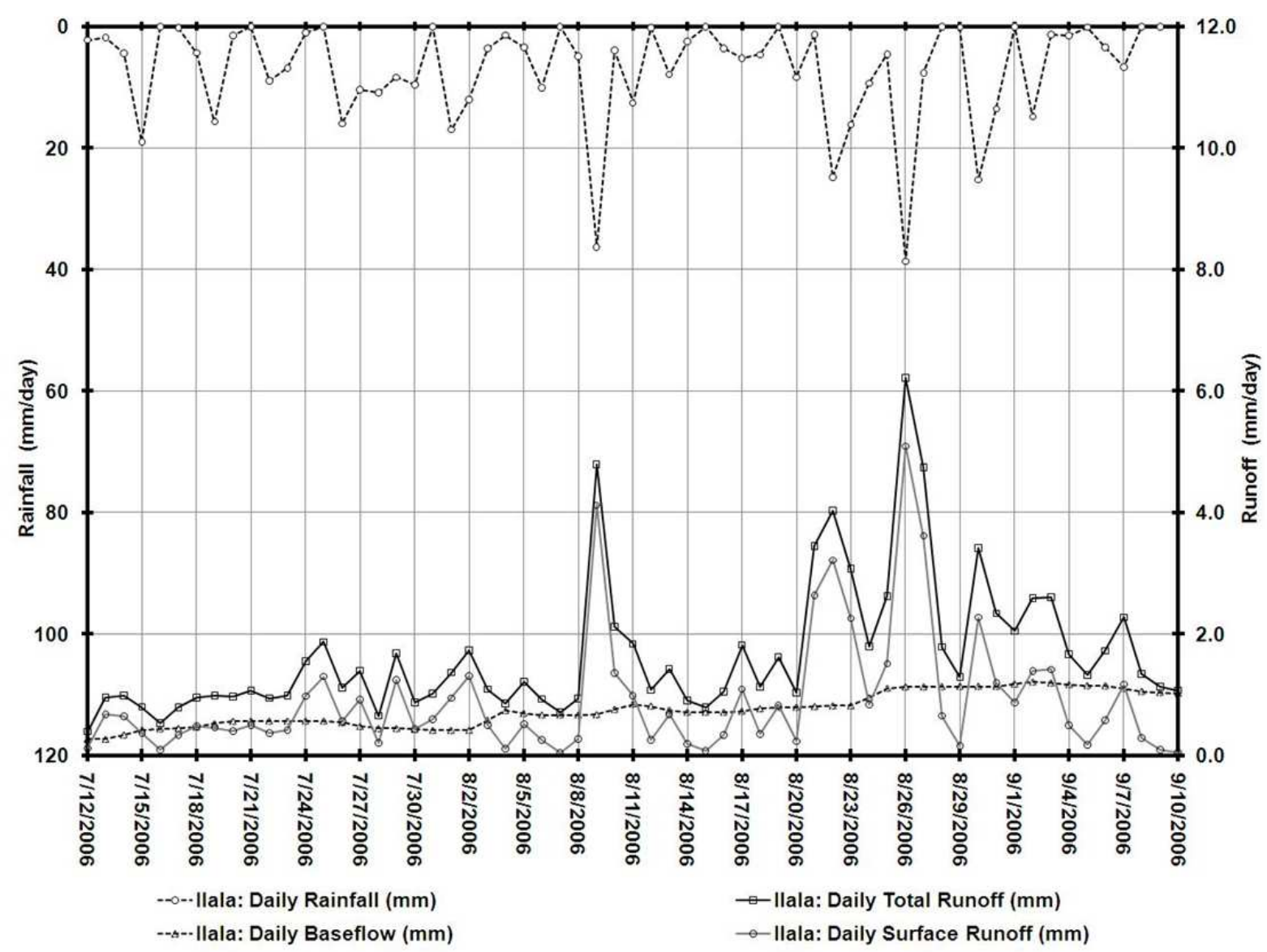

Fig. 7: Daily rainfall, total runoff, surface (or direct) runoff and baseflow depths for the Ilala catchment during the measuring campaign of 2006. 

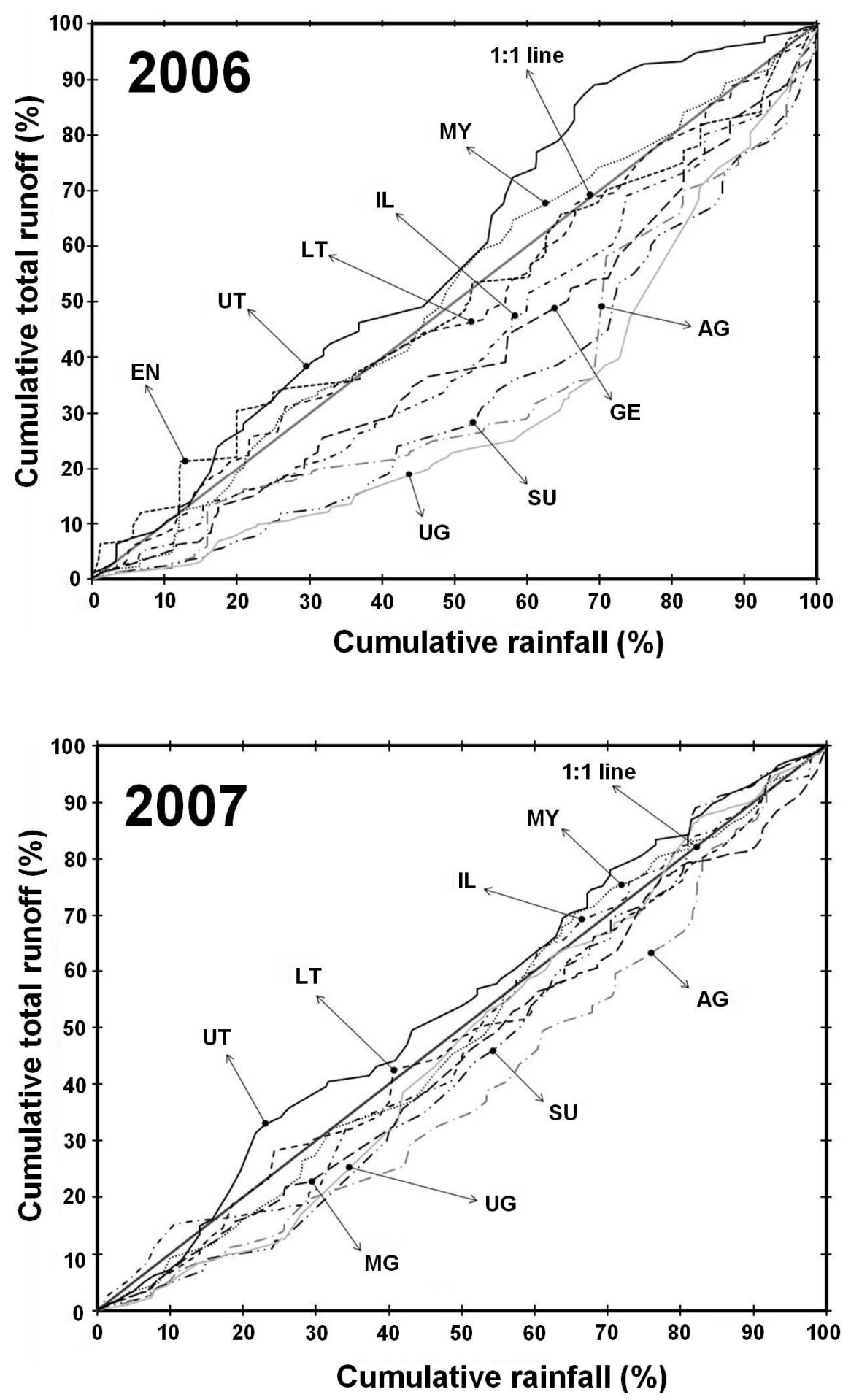

Fig. 8: Normalised cumulative total runoff versus cumulative rainfall for all flow gauges, using data from the measuring campaigns of 2006 (top) and 2007 (bottom) 


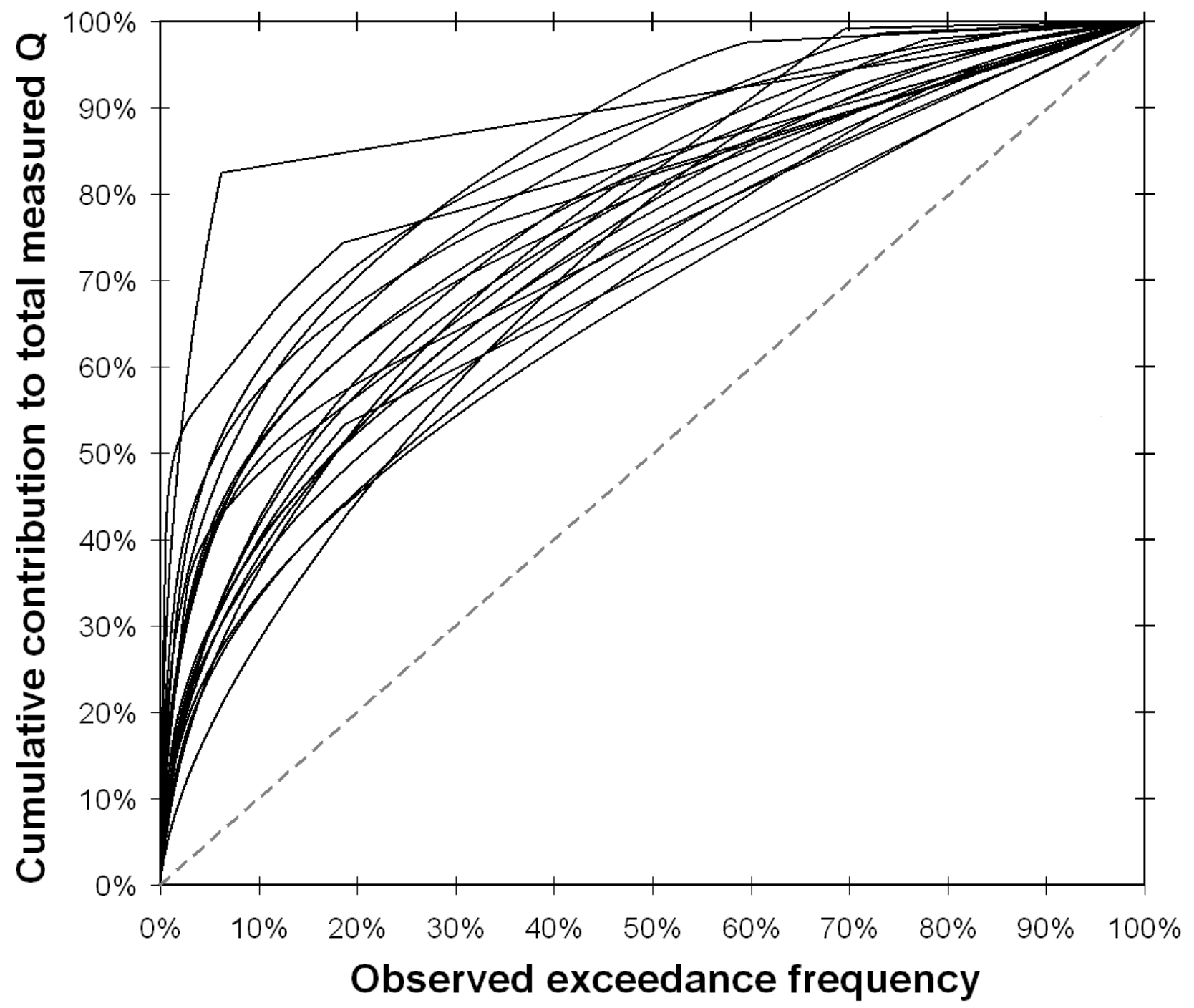

Fig. 9: The cumulative contribution of all recorded (10 min. interval) runoff discharges to the total measured seasonal discharge, according to their observed exceedance frequency for all available flow gauges and measuring campaigns $(\mathrm{n}=21)$. 

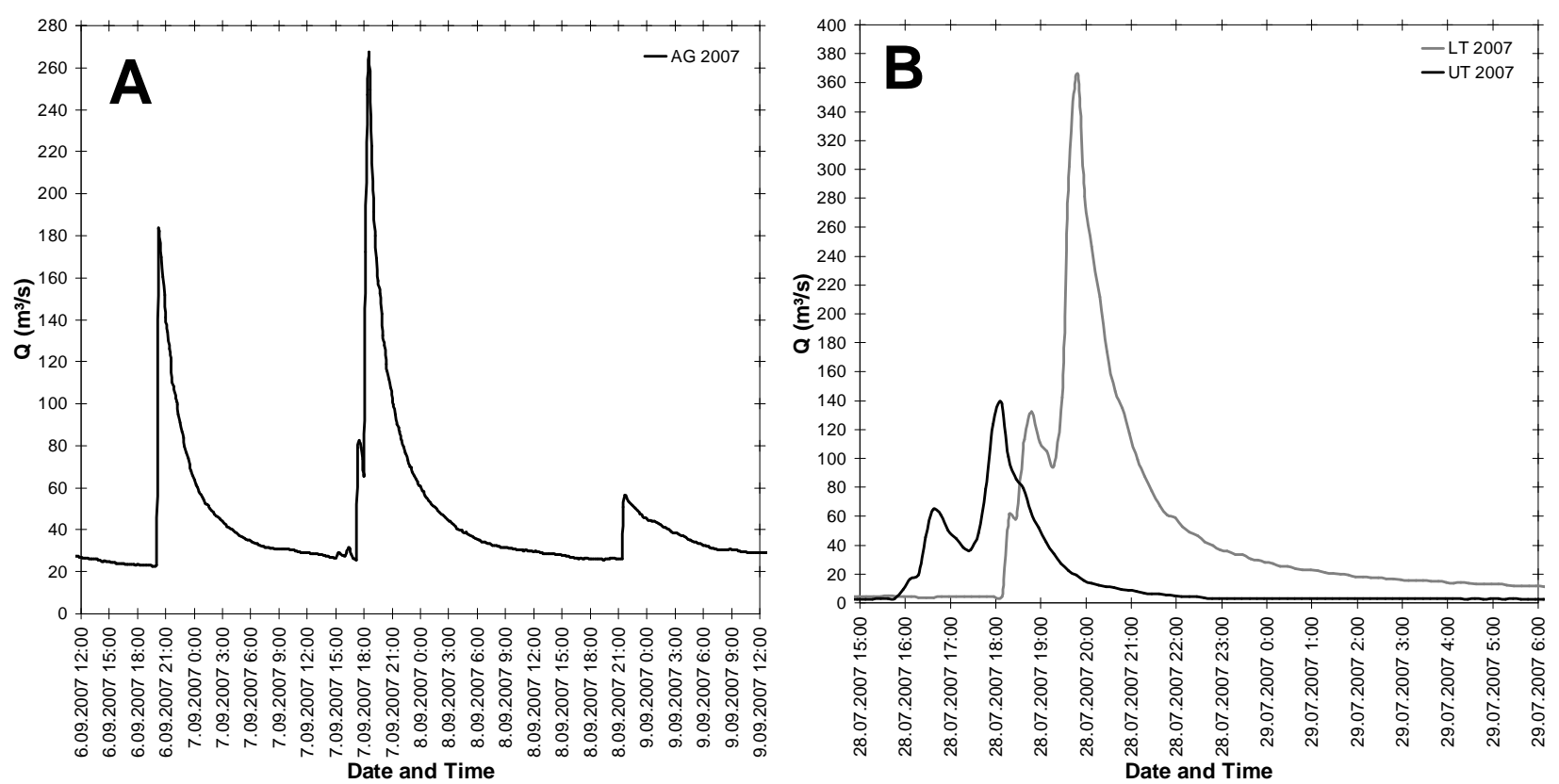

Fig. 10. Flash flood hydrographs, recorded by the TD divers and converted into instantaneous discharge (Q) series, for (A) Agula flow gauge (6/9/2007-9/9/2007), and (B) Upper and Lower Tankwa gauges (2829/7/2007). 


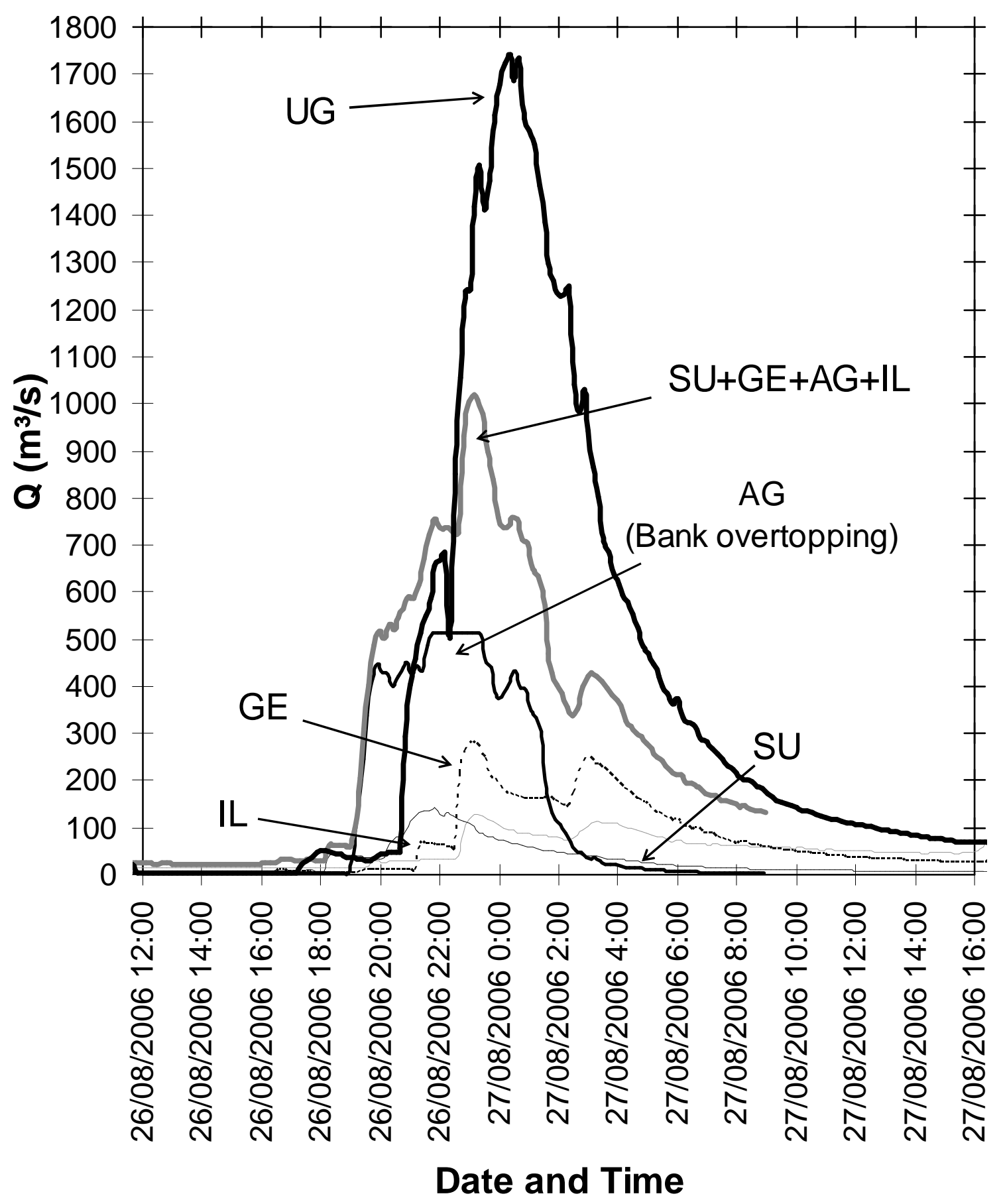

Fig. 11: Hydrograph of Upper Geba and its monitored tributaries during the flash flood of August 26-27 2006. 


\section{TABLES}

Table 1: Characteristics of the monitored subcatchments of the Geba river

\begin{tabular}{|c|c|c|c|c|c|c|c|c|c|c|}
\hline & Suluh & Genfel & Agula & Ilala & $\begin{array}{l}\text { Upper } \\
\text { Geba }\end{array}$ & $\begin{array}{c}\text { May } \\
\text { Gabat }\end{array}$ & $\begin{array}{c}\text { Enda- } \\
\text { selassie }\end{array}$ & $\begin{array}{c}\text { Middle } \\
\text { Geba }\end{array}$ & $\begin{array}{c}\text { Upper } \\
\text { Tankwa }\end{array}$ & $\begin{array}{c}\text { Lower } \\
\text { Tankwa }\end{array}$ \\
\hline Abbreviation & SU & GE & $\mathrm{AG}$ & IL & UG & MY & EN & MG & UT & $\mathrm{LT}$ \\
\hline \multirow{2}{*}{ Station location } & $13^{\circ} 38^{\prime} 57^{\prime \prime}$ & $13^{\circ} 38^{\prime} 49^{\prime \prime}$ & $13^{\circ} 37^{\prime} 31^{\prime \prime}$ & $13^{\circ} 35^{\prime} 01^{\prime \prime}$ & $13^{\circ} 32^{\prime} 27^{\prime \prime}$ & $13^{\circ} 28^{\prime} 15^{\prime \prime}$ & $13^{\circ} 29^{\prime} 30^{\prime \prime}$ & $13^{\circ} 30^{\prime} 40^{\prime \prime}$ & $13^{\circ} 366^{\prime \prime}$ & $13^{\circ} 32^{\prime} 15^{\prime \prime}$ \\
\hline & $39^{\circ} 24^{\prime} 47^{\prime \prime}$ & $39^{\circ} 25^{\prime} 07^{\prime \prime}$ & $39^{\circ} 24^{\prime} 28^{\prime \prime}$ & $39^{\circ} 23^{\prime} 19^{\prime \prime}$ & $39^{\circ} 21^{\prime} 21^{\prime \prime}$ & $39^{\circ} 17^{\prime} 51^{\prime \prime}$ & $39^{\circ} 12^{\prime} 28^{\prime \prime}$ & $38^{\circ} 53^{\prime} 41^{\prime \prime}$ & $38^{\circ} 59^{\prime} 51^{\prime \prime}$ & $38^{\circ} 53^{\prime} 34^{\prime \prime}$ \\
\hline Monitored years & $\begin{array}{c}2004 ; 2006 \\
2007\end{array}$ & 2006 & $2005-2007$ & 2004-2007 & 2006-2007 & 2006-2007 & 2006 & 2007 & 2006-2007 & 2006-2007 \\
\hline $\mathrm{A}\left(\mathrm{km}^{2}\right)$ & 969 & 733 & 692 & 341 & 2957 & 652 & 121 & 4592 & 130 & 216 \\
\hline $\begin{array}{l}\text { Monitored } \\
\text { tributaries }\end{array}$ & & & & & $\begin{array}{c}\text { SU GE AG } \\
\text { IL }\end{array}$ & & & $\begin{array}{c}\text { UG MY } \\
\text { EN }\end{array}$ & & UT \\
\hline $\operatorname{Hmin}(m . a . s .1)$ & 1777 & 1778 & 1764 & 1740 & 1702 & 1612 & 1484 & 1288 & 1814 & 1290 \\
\hline $\operatorname{Hmax}($ m.a.s.l) & 3298 & 3067 & 2859 & 2676 & 3298 & 2759 & 2812 & 3298 & 2824 & 2824 \\
\hline Hmean (m.a.s.l) & 2320 & 2453 & 2280 & 2222 & 2312 & 2147 & 2157 & 2193 & 2362 & 2098 \\
\hline HD (m) & 1521 & 1289 & 1095 & 936 & 1596 & 1147 & 1328 & 2010 & 1010 & 1534 \\
\hline $\operatorname{ACS}(\%)$ & 14.3 & 17.8 & 15.8 & 9.5 & 15.1 & 12.6 & 21.0 & 15.7 & 26.7 & 23.6 \\
\hline $\operatorname{BAS}(\%)$ & 7.6 & 0.0 & 0.0 & 0.0 & 2.5 & 0.1 & 5.0 & 2.4 & 42.3 & 25.6 \\
\hline $\operatorname{DOL}(\%)$ & 0.0 & 0.0 & 3.0 & 22.8 & 3.7 & 22.0 & 11.4 & 6.3 & 0.0 & 0.0 \\
\hline $\operatorname{GRA}(\%)$ & 4.8 & 0.2 & 0.0 & 0.0 & 1.6 & 0.0 & 0.0 & 1.0 & 0.0 & 0.0 \\
\hline $\operatorname{LST}(\%)$ & 23.1 & 13.0 & 47.1 & 19.3 & 29.0 & 27.9 & 55.5 & 30.8 & 3.0 & 1.5 \\
\hline $\operatorname{LSM}(\%)$ & 4.1 & 3.4 & 17.6 & 57.9 & 13.5 & 38.4 & 11.6 & 15.5 & 9.8 & 5.9 \\
\hline $\operatorname{MET}(\%)$ & 20.1 & 50.5 & 14.1 & 0.0 & 25.2 & 0.0 & 0.0 & 21.7 & 0.1 & 37.1 \\
\hline $\operatorname{SST}(\%)$ & 39.2 & 25.1 & 8.4 & 0.0 & 18.4 & 0.7 & 12.4 & 16.2 & 44.9 & 30.0 \\
\hline SHA $(\%)$ & 1.0 & 7.8 & 9.8 & 0.0 & 6.1 & 10.8 & 4.1 & 5.9 & 0.0 & 0.0 \\
\hline $\mathrm{BaL}(\%)$ & 26.3 & 20.9 & 20.1 & 13.2 & 21.5 & 11.1 & 23.9 & 18.6 & 9.3 & 10.1 \\
\hline BUA (\%) & 2.1 & 3.1 & 1.8 & 6.7 & 2.8 & 3.7 & 0.4 & 2.9 & 0.5 & 4.5 \\
\hline BGL (\%) & 22.3 & 27.1 & 24.9 & 13.5 & 24.1 & 18.4 & 33.3 & 24.9 & 48.7 & 37.1 \\
\hline CL (\%) & 39.7 & 39.4 & 40.7 & 60.8 & 41.9 & 62.8 & 27.1 & 45.2 & 30.0 & 40.1 \\
\hline FL (\%) & 0.3 & 0.4 & 1.0 & 0.3 & 0.5 & 0.3 & 0.7 & 0.4 & 1.8 & 1.3 \\
\hline GL (\%) & 9.3 & 9.0 & 11.5 & 5.1 & 9.1 & 3.5 & 14.6 & 7.8 & 9.6 & 6.8 \\
\hline WB $(\%)$ & 0.1 & 0.1 & 0.0 & 0.4 & 0.1 & 0.1 & 0.1 & 0.1 & 0.1 & 0.2 \\
\hline $\operatorname{SBD}\left(\mathrm{km} \mathrm{km}^{-2}\right)$ & 4.0 & 3.8 & 4.2 & 5.6 & 4.1 & 4.0 & 3.2 & 3.8 & 3.3 & 3.1 \\
\hline
\end{tabular}

A: catchment area $\left(\mathrm{km}^{2}\right)$; Hmin: minimum elevation in subcatchment (m); Hmax: maximum elevation in subcatchment (m); Hmean: mean elevation in subcatchment (m); HD: height difference (m); ACS: average catchment slope (\%); CC (dimensionless): compactness coefficient; B AS (\%): Trap basalt; DOL (\%): Dolerite; GRA (\%): Granite; LST (\%): Limestone; LSM (\%): Limestone-Marl; MET (\%): Metamorphic rock; SST (\%): Sandstone; SHA (\%): Shale; BaL (\%): Bare land; BUA (\%): Built Up Area; BGL (\%): Bushed Grass Land; CL (\%): Cultivated Land; FL (\%): Forest land; GL (\%): Grass Land; WB (\%): Water body; SBD: Stone bund density (km/km²). 
Table 2: Periods of missing TD-diver records during the measuring campaigns of 2004-2007 and models used to predict the daily runoff discharges $\left(\mathrm{Qd}, \mathrm{m}^{3} \mathrm{day}^{-1}\right)$ for those days. 'dmax' is the maximum, manually recorded flow depth of the day for which no TD-diver records are available.

\begin{tabular}{|c|c|c|}
\hline \multirow{3}{*}{$\frac{\text { Station }}{\mathrm{AG}}$} & Period of missing data & Prediction model Qd \\
\hline & 2006: July 27 (1 day) & $\mathrm{Qd}=1 * 10^{6} * \mathrm{dmax}-66258$ \\
\hline & 2006: Aug 28 - Sep 7 (11 days) & $\left(\mathrm{R}^{2}=0.47, \mathrm{n}=152\right)$ \\
\hline UG & 2006: July $12-22$ (11 days) & $\begin{array}{l}\mathrm{Qd}=3 * 10^{-4} *\left(\mathrm{Qd} \_\mathrm{SU}+\mathrm{GE}+\mathrm{AG}+\mathrm{IL}\right)^{1.48} \\
\left(\mathrm{R}^{2}=0.73, \mathrm{n}=50\right)\end{array}$ \\
\hline EN & 2006: July 12-15 (4 days) \& & $\mathrm{Qd}=1.48 * 10^{5} * \mathrm{dmax}^{0.76}$ \\
\hline & July 24 - Aug 5 (13 days) & $\left(\mathrm{R}^{2}=0.64, \mathrm{n}=42\right)$ \\
\hline MG & 2007: Aug 6 - 11 (6 days) & $\begin{array}{l}\mathrm{Qd}=0.89 * 10^{6} *\left(\mathrm{Qd} \_\mathrm{OB}+\mathrm{MY}\right)+1 * 10^{6} \\
\left(\mathrm{R}^{2}=0.80, \mathrm{n}=76\right)\end{array}$ \\
\hline UT & 2006: Aug. 6- Aug.21 (16 days) & $\begin{array}{l}\mathrm{Qd}=48720 \mathrm{dmax}+16249 \\
\left(\mathrm{R}^{2}=0.33, \mathrm{n}=94\right)\end{array}$ \\
\hline LT & 2006: Aug. 7- Aug.20 (14 days) & $\begin{array}{l}\mathrm{Qd}=66328 \mathrm{dmax}+33476 \\
\left(\mathrm{R}^{2}=0.50, \mathrm{n}=159\right)\end{array}$ \\
\hline
\end{tabular}


Table 3: Flow depth $(\mathrm{d}, \mathrm{m})$ - runoff discharge $\left(\mathrm{Q}, \mathrm{m}^{3} \mathrm{~s}^{-1}\right)$ relationships for all flow gauges within Geba catchment.

\begin{tabular}{|c|c|c|c|c|}
\hline Station & $\mathrm{d}-\mathrm{Q}$ equation & $\mathrm{n}$ & $\mathrm{R}^{2}$ & Remark \\
\hline SU & $\mathrm{Q}=23.6 * \mathrm{~d}^{2.14}$ & 295 & 0.93 & data from $2005-2007$ \\
\hline GE & $\mathrm{Q}=12.23 * \mathrm{~d}^{2.11}$ & 279 & 0.96 & data from $2005-2007$ \\
\hline AG & $\mathrm{Q}=8.05 * \mathrm{~d}^{2.35}$ & 288 & 0.97 & data from $2005-2007$ \\
\hline $\mathrm{IL}$ & $\mathrm{Q}=9.42 * \mathrm{~d}^{2.36}$ & 180 & 0.99 & data from $2005-2006$ \\
\hline UG & $\mathrm{Q}=20.23 * \mathrm{~d}^{2.19}$ & 242 & 0.95 & data from 2006-2007 \\
\hline MY & $\mathrm{Q}=17.89 * \mathrm{~d}^{1.91}$ & 266 & 0.92 & data from 2006-2007 \\
\hline $\mathrm{EN}$ & $\mathrm{Q}=8.81 * \mathrm{~d}^{2.32}$ & 237 & 0.98 & data from 2006-2007 \\
\hline $\mathrm{UT}^{\mathrm{a}}$ & $\mathrm{Q}=5.51 * \mathrm{~d}^{3.49}$ & 68 & 0.94 & first cross-section. Data from 2006 \\
\hline $\mathrm{UT}^{\mathrm{a}}$ & $\mathrm{Q}=46.22 * \mathrm{~d}^{1.97}$ & 161 & 0.99 & new cross-section. Data from 2007 \& part 2006 \\
\hline $\mathrm{LT}$ & $\mathrm{Q}=37.33 * \mathrm{~d}^{2.20}$ & 162 & 0.99 & data from 2007 \\
\hline MG & $\mathrm{Q}=11.66 * \mathrm{~d}^{2.58}$ & 131 & 0.98 & data from 2007 \\
\hline
\end{tabular}

${ }^{\mathrm{a}}$ Two rating curves were developed for the UT station because a new channel cross-section was selected after a large flash flood destroyed the gauging station on 8 Aug. 2006 . 
Table 4: Seasonal cumulative river discharge volume $\left(\mathrm{Qs}, \mathrm{m}^{3}\right)$, seasonal total runoff depth (TRs, $\mathrm{mm}$ ); predicted river discharge ( $\mathrm{Qp}$, i.e. the percentage of Qs that was predicted, using the equations indicated in Table 2); estimated seasonal baseflow (BFs, mm); total runoff coefficient (TRC, \%); direct runoff coefficient (DRC, \%); seasonal rainfall (Ps, mm); percent of annual rainfall measured (Pm, \%); annual rainfall (Pa, $\mathrm{mm})$; annual total river discharge $\left(\mathrm{Qa}, \mathrm{m}^{3}\right)$; annual total runoff depth (TRa , mm); and the largest measured instananeous discharge (Qmax, $\left.\mathrm{m}^{3} \mathrm{~s}^{-1}\right)$ of the monitored catchments. Each year, measuring campaigns were held from July 12 to September 10.

\begin{tabular}{|c|c|c|c|c|c|c|c|c|c|c|c|c|c|}
\hline Station & Year & $\begin{array}{c}\text { Qs } \\
\left(10^{6} \mathrm{~m}^{3}\right)\end{array}$ & $\begin{array}{c}\text { TRs } \\
(\mathrm{mm})\end{array}$ & Qp (\%) & BFs (mm) & $\begin{array}{c}\text { TRCs } \\
(\%)\end{array}$ & $\begin{array}{c}\text { DRCs } \\
(\%)\end{array}$ & Ps (mm) & $\operatorname{Pm}(\%)$ & $\mathbf{P a}(\mathrm{mm})$ & $\begin{array}{c}\text { Qa } \\
\left(10^{6} \mathrm{~m}^{3}\right)\end{array}$ & $\begin{array}{c}\text { TRa } \\
(\mathbf{m m})\end{array}$ & $\begin{array}{r}\text { Qmax } \\
\left(\mathrm{m}^{3} \mathrm{~s}^{-1)}\right.\end{array}$ \\
\hline SU & 2004 & 57 & 59 & 0 & 17 & 19 & 13 & 319 & 64 & 497 & 90 & 92 & 196 \\
\hline SU & 2006 & 107 & 110 & 0 & 53 & 26 & 14 & 418 & 61 & 690 & 177 & 182 & 248 \\
\hline SU & 2007 & 74 & 76 & 0 & 29 & 20 & 12 & 383 & 55 & 694 & 134 & 138 & 338 \\
\hline SU & Avg. & 79 & 82 & 0 & 33 & 22 & 13 & 373 & 60 & 627 & 133 & 138 & - \\
\hline GE & 2006 & 51 & 69 & 0 & 15 & 16 & 12 & 441 & 67 & 656 & 76 & 103 & 300 \\
\hline GE & Avg. & 51 & 69 & $\mathbf{0}$ & 15 & 16 & 12 & 441 & 67 & 656 & 76 & 103 & - \\
\hline $\mathrm{AG}$ & 2005 & 23 & 34 & 0 & 6 & 9 & 7 & 390 & 73 & 531 & 32 & 46 & 404 \\
\hline AG & 2006 & 37 & 53 & 26 & 21 & 12 & 7 & 425 & 64 & 661 & 57 & 82 & 520 \\
\hline AG & 2007 & 168 & 242 & 0 & 135 & 46 & 20 & 525 & 65 & 804 & 257 & 371 & 325 \\
\hline AG & Avg. & 76 & 110 & 9 & 54 & 22 & 12 & 447 & 68 & 665 & 115 & 166 & - \\
\hline IL & 2004 & 32 & 94 & 0 & 52 & 34 & 15 & 280 & 72 & 390 & 45 & 131 & 184 \\
\hline IL & 2005 & 27 & 78 & 0 & 26 & 19 & 13 & 416 & 70 & 598 & 38 & 113 & 183 \\
\hline IL & 2006 & 35 & 102 & 0 & 46 & 24 & 13 & 432 & 62 & 691 & 55 & 163 & 144 \\
\hline IL & 2007 & 32 & 94 & 0 & 33 & 22 & 15 & 422 & 61 & 693 & 53 & 155 & 259 \\
\hline IL & Avg. & 31 & 92 & 0 & 39 & 25 & 14 & 387 & 66 & 593 & 48 & 140 & - \\
\hline UG & 2006 & 161 & 55 & 3 & 8 & 13 & 11 & 423 & 63 & 670 & 255 & 86 & 1740 \\
\hline UG & 2007 & 167 & 56 & 0 & 9 & 12 & 10 & 455 & 64 & 716 & 262 & 89 & 1285 \\
\hline UG & Avg. & 164 & 55 & 2 & 9 & 13 & 11 & 439 & 63 & 693 & 259 & 88 & - \\
\hline MY & 2006 & 37 & 56 & 0 & 19 & 13 & 8 & 443 & 65 & 683 & 56 & 87 & 109 \\
\hline MY & 2007 & 43 & 66 & 0 & 22 & 13 & 9 & 499 & 71 & 706 & 60 & 93 & 190 \\
\hline MY & Avg. & 40 & 61 & 0 & 21 & 13 & 9 & 471 & 68 & 695 & 58 & 90 & - \\
\hline EN & 2006 & 7 & 55 & 21 & 20 & 15 & 10 & 362 & 50 & 720 & 13 & 110 & 172 \\
\hline EN & Avg. & 7 & 55 & 21 & 20 & 15 & 10 & 362 & 50 & 720 & 13 & 110 & - \\
\hline MG & 2007 & 261 & 57 & 9 & 18 & 12 & 8 & 481 & 54 & 884 & 479 & 104 & 551 \\
\hline MG & Avg. & 261 & 57 & 9 & 18 & 12 & 8 & 481 & 54 & 884 & 479 & 104 & - \\
\hline UT & 2006 & 21 & 159 & 44 & 78 & 30 & 15 & 533 & 56 & 947 & 37 & 283 & 139 \\
\hline UT & 2007 & 28 & 212 & 0 & 87 & 34 & 20 & 626 & 61 & 1025 & 45 & 347 & 270 \\
\hline UT & Avg. & 24 & 186 & 22 & 83 & 32 & 18 & 580 & 59 & 986 & 41 & 315 & - \\
\hline LT & 2006 & 46 & 212 & 32 & 122 & 41 & 17 & 522 & 64 & 820 & 72 & 333 & 225 \\
\hline LT & 2007 & 61 & 281 & 0 & 114 & 47 & 28 & 599 & 71 & 842 & 85 & 395 & 543 \\
\hline LT & Avg. & 53 & 246 & 16 & 118 & 44 & 23 & 561 & 67 & 831 & 79 & 364 & - \\
\hline
\end{tabular}

